\title{
DAMPening Inflammation by Modulating TLR Signalling
}

\author{
A. M. Piccinini and K. S. Midwood \\ Kennedy Institute of Rheumatology Division, Faculty of Medicine, Imperial College of Science, Technology and Medicine, \\ 65 Aspenlea Road, Hammersmith, London W6 8LH, UK
}

Correspondence should be addressed to K. S. Midwood, k.midwood@imperial.ac.uk

Received 27 November 2009; Accepted 20 April 2010

Academic Editor: Andrew Parker

Copyright (C) 2010 A. M. Piccinini and K. S. Midwood. This is an open access article distributed under the Creative Commons Attribution License, which permits unrestricted use, distribution, and reproduction in any medium, provided the original work is properly cited.

\begin{abstract}
Damage-associated molecular patterns (DAMPs) include endogenous intracellular molecules released by activated or necrotic cells and extracellular matrix (ECM) molecules that are upregulated upon injury or degraded following tissue damage. DAMPs are vital danger signals that alert our immune system to tissue damage upon both infectious and sterile insult. DAMP activation of Toll-like receptors (TLRs) induces inflammatory gene expression to mediate tissue repair. However, DAMPs have also been implicated in diseases where excessive inflammation plays a key role in pathogenesis, including rheumatoid arthritis (RA), cancer, and atherosclerosis. TLR activation by DAMPs may initiate positive feedback loops where increasing tissue damage perpetuates pro-inflammatory responses leading to chronic inflammation. Here we explore the current knowledge about distinct signalling cascades resulting from self TLR activation. We also discuss the involvement of endogenous TLR activators in disease and highlight how specifically targeting DAMPs may yield therapies that do not globally suppress the immune system.
\end{abstract}

\section{The Danger Hypothesis}

Both infection and sterile tissue injury generate strong immune responses. This paradox was first resolved by Matzinger in 1994 who proposed that our immune system is designed to combat danger, rather than mediate recognition of non-self over self [1]. Pathogen-associated molecular patterns (PAMPs) and endogenous molecules created upon tissue injury, since called damage-associated molecular patterns (DAMPs), signal the threat of either infection or injury to the organism, independently of their non-self- or self-identity [2-5]. Among the cellular receptors that sense these danger signals, Toll-like receptors (TLRs) represent a key molecular link between tissue injury, infection, and inflammation. In the last decade a number of endogenous molecules specifically generated upon tissue injury that activate TLRs have been identified. Some are intracellular molecules normally inaccessible to the immune system that are released into the extracellular milieu as a result of cell necrosis or activation following injury. Others are extracellular matrix (ECM) molecule fragments that are released upon tissue damage or ECM molecules that are specifically upregulated in response to tissue injury [6].
In addition to playing a key role in host defence against danger, activation of TLRs has been linked to the pathogenesis of many inflammatory and autoimmune diseases including sepsis, rheumatoid arthritis (RA), systemic lupus erythematosus (SLE), inflammatory bowel disease (IBD), type I diabetes, and multiple sclerosis (MS). Hence, in recent years TLRs and associated signalling molecules have become attractive targets for their treatment and a number of inhibitors are currently in development or have progressed to clinical trials. Aberrant TLR activation is also thought to contribute to diseases with a strong association with inflammation such as cancer and atherosclerosis (reviewed in [7-11]).

One of the key questions to emerge from these studies is what factors drive TLR activation during the progression of disease. There is an increasing body of evidence to suggest that DAMP-mediated inflammation plays a vital role. It is also becoming apparent that PAMPs and DAMPs act in quite a different manner in order to stimulate an immune response. Here we review the mechanisms of DAMP recognition by TLRs, the signalling cascades, and the biological outcomes resulting from self TLR activation, focusing on the differences to non-self TLR activation. 
We also discuss the evidence that implicates endogenous molecules in pathological TLR activation and examine how blockade of DAMP action may be therapeutically beneficial. Understanding more about the differences between PAMPand DAMP-induced inflammation may enable us to specifically target inappropriate, pathogenic inflammation whilst leaving the host defence intact.

\section{Endogenous Activators of TLRs}

The first report of a putative endogenous activator of TLRs dates back to 2000, when heat shock protein 60 (HSP60) was shown to induce cytokine synthesis through TLR4 activation [12]. In the same year necrotic cells were found to induce pro-inflammatory and tissue repair gene synthesis and cause DC maturation in a TLR2 dependent manner, as a result of the release of their intracellular contents $[13,14]$. The list of endogenous TLR2 and 4 activators has expanded quickly and encompasses other intracellular molecules such as heat shock proteins including HSP70, Gp96 [15-17], HSP22, and HSP72 $[18,19]$ and high-mobility group box-1 protein (HMGB1) [20-22] as well as ECM molecules such as biglycan [23], tenascin-C [24], versican [25], and fragments of ECM molecules including oligosaccharides of hyaluronic acid (HA) [26] and heparan sulfate (HS) [27].

Notably, the list of TLRs activated by endogenous molecules is also expanding. For instance, TLR1 was shown for the first time to be required, along with TLR2, for the activation of professional antigen-presenting cells by $\beta$ defensin-3, a host-derived antimicrobial peptide [28]. Selfnucleic acids have also been described as endogenous danger signals, namely, mRNA recognised by TLR3 [29], singlestranded RNA (ssRNA) sensed by TLR7 and 8 [30], and IgGchromatin complexes recognised by TLR9 [31]. Interestingly, emerging data support the activation of TLR7 and 8 by antiphospholipid antibodies (APL) isolated from patients with APL syndrome $[32,33]$, as has been also shown previously for TLR2 and 4 [34-36]. A more complete list of DAMPs and their cognate TLRs can be found in Figure 1.

Given the use of E. coli to produce many of these endogenous molecules recombinantly, and the fact that most endogenous proteins activate TLR2 and 4, originally described as sensors of microbial products such as lipopolysaccharides (LPSs) and lipoproteins, the question of whether microbial contamination can partially or wholly account for DAMP activity remains a key issue. Erridge and Samani recently showed that apparent stimulation of TLR4 by saturated fatty acids was due to microbial contamination in their preparations of BSA [37]. In contrast, professional antigen-presenting cells that are not responsive to LPS were shown to be activated by necrotic cells indicating that LPS independent TLR4 activation does occur in response to endogenous ligands [38]. Similar to TLR2, TLR3 was also shown to recognize cells undergoing necrosis during acute inflammatory events, independently of viral infection [39]. Indeed, as details of the mechanisms of endogenous TLR ligand recognition emerge, it becomes clear that there are significant differences between PAMP and DAMP activation of TLRs. We discuss these differences in detail in the following sections of this review. In addition, the phenotype of mice with targeted deletions in a number of endogenous TLR activators confirms that removal of endogenous danger signals correlates with the effects of addition of exogenous DAMPs. Together these data indicate that DAMP activity is not reliant on the presence of contaminating PAMPs.

Recent data indicate that endogenous danger signals and microbial products can also cooperate in the induction of immune responses. Neither highly purified HSP preparations nor LPS alone at concentrations corresponding to those found in contaminated HSP preparations could induce proinflammatory cytokine production (reviewed in [40-42]). Further studies showed that HSP60 and Gp96 can tightly bind to LPS in a saturable manner and enhance its biological activity, as well as that of the TLR2 ligand $\mathrm{Pam}_{3}$ Cys [4345]. In the light of these results, the function of HSPs has been proposed to modulate early immune responses during infection by mediating a synergy between PAMPs and DAMPs. Similarly, HSP90 has also been implicated in the recognition of CPG DNA by TLR9 and the binding of HMGBs to nucleic acids is required for efficient recognition by TLR3, 7 , and 9 [46-48].

\section{Mechanisms of TLR Activation by DAMPs versus PAMPs}

There is an increasing body of evidence that demonstrates how exogenous and endogenous activation of TLRs is mediated and this reveals that, whilst there is some overlap in molecular machinery, DAMPs possess distinct mechanisms of action to PAMPs. These similarities and differences emerge below where we explore the mechanisms of PAMP and DAMP recognition by TLRs and the subsequent TLR signalling and biological outcomes.

\subsection{Ligand Recognition by TLRs}

3.1.1. Exogenous Ligand Recognition. TLRs interact with a wide variety of ligands ranging from proteins and lipoproteins to nucleic acids and saccharides, all of which are different in size and chemical properties. The extracellular domains (ECDs) of TLRs contain leucine-rich repeat (LRR) motifs that are responsible for PAMP recognition [49]. The crystal structures of three TLR ECD-ligand complexes have been solved. One structure shows that TLR3 interacts with hydrophilic double-stranded RNA (dsRNA) via surfaceexposed sites [50]. A second structure shows TLR1-TLR2 heterodimers bound to the hydrophobic $\mathrm{Pam}_{3} \mathrm{CSK}_{4}$ lipopeptide that fits in an internal hydrophobic pocket [51]. Finally, the structure of the TLR4-MD-2-LPS complex shows that TLR4 employs the co-receptor MD-2 to recognise LPS and that no direct contacts between the receptor and the ligand take place [52-54]. The latter structure also provided insights into the structure-activity relationship of the lipid A moiety of LPS. Not only the number of lipid chains $[55,56]$ but also the phosphate groups and their positioning in the lipid $A$ are important factors affecting the immunological activity 

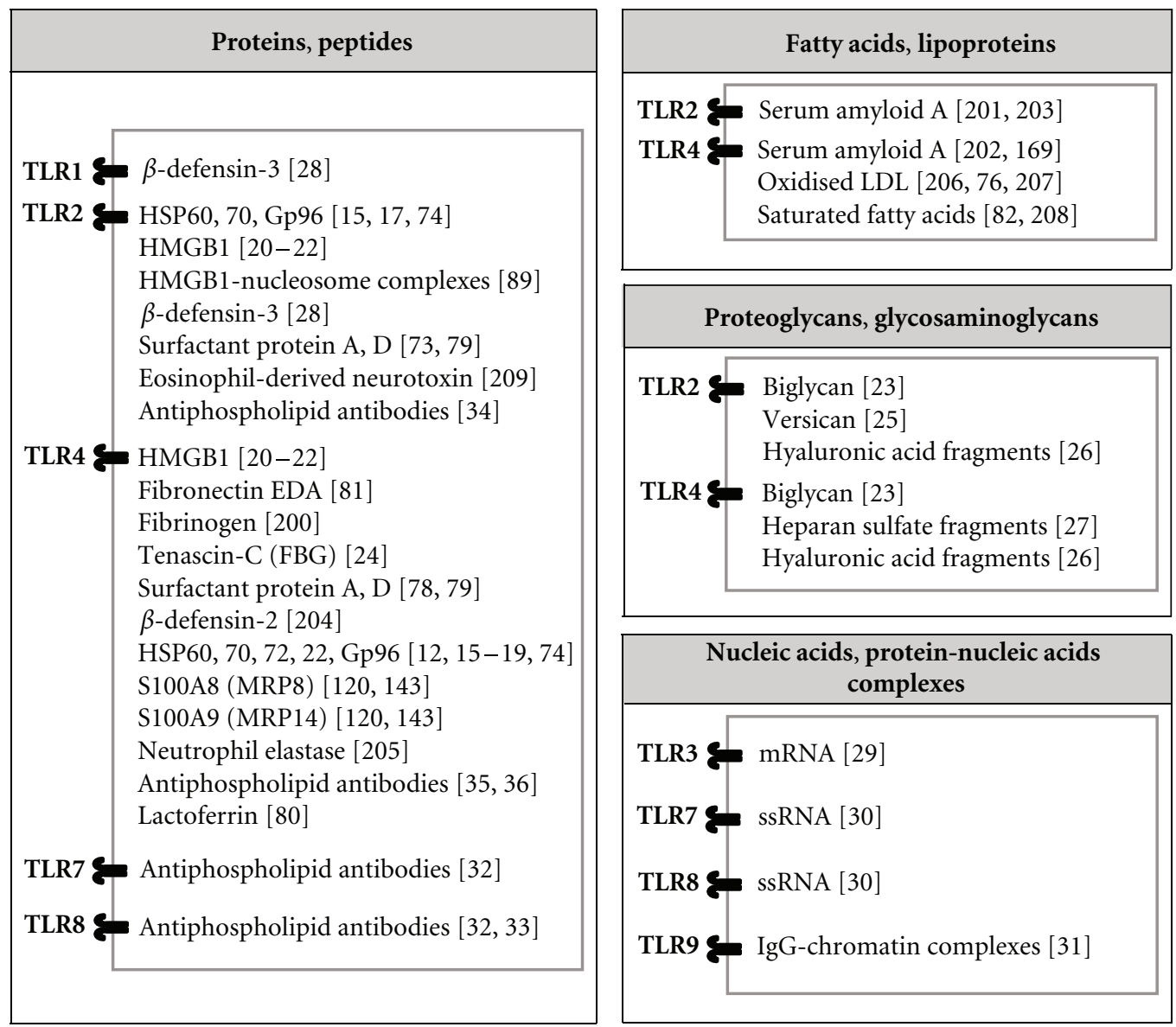

FIGURE 1: Endogenous TLR activators. TLRs are activated by damage-associated molecular patterns (DAMPs) including intracellular molecules released in the extracellular milieu by activated or necrotic cells and extracellular matrix molecules either upregulated upon injury or degraded following tissue damage. Known endogenous TLR activators are listed based on their biochemical nature.

of LPS [53]. This suggests that even minor modifications to ligands may cause significant changes in the responses they generate.

These three crystal structures highlight three diverse modes of exogenous ligand recognition by TLRs involving TLR homo- and heterodimerization as well as direct TLRligand interactions or the use of co-receptors and accessory molecules. A number of accessory molecules have been shown to assist microbial recognition by TLRs. For instance, LPS is extracted from the bacterial membrane by the LPSbinding protein (LBP) after which it is transferred to CD14. Subsequent transfer from CD14 to an additional accessory molecule MD-2 then allows TLR4-mediated LPS recognition [57]. Interestingly, in the absence of MD-2, the LPS-dependent TLR4 signalling can be reconstituted by the mite dust allergen Der p 2, which has structural and functional homology with MD-2 and mimics the activity of MD-2 by presenting LPS to TLR4 $[58,59]$. HMGB1 can also mediate LPS transfer to CD14 to initiate a TLR4-mediated pro-inflammatory response [60]. In B cells, the TLR-like molecule radioprotective 105 (RP105) forms a complex with the MD-2 homolog MD-1 and is essential for regulating TLR2 and 4-dependent antibody production to the ligands lipoproteins and LPS. Conversely, in macrophages and
DCs, RP105/MD-1 acts as a TLR4 decoy receptor that, by interacting directly with the TLR4 signalling complex, inhibits the ability of the receptor to bind microbial ligands $[61,62]$. Other accessory molecules bind directly to TLR ligands. CD14 facilitates LPS transfer to TLR4/MD-2 and, accordingly, in the absence of CD14 rough LPS cannot initiate the TRIF/TRAM pathway and smooth LPS cannot be detected at all $[63,64]$. CD14 binds also to triacylated lipopeptides facilitating their recognition by TLR2/TLR1 complexes [65] and can enhance dsRNA-mediated TLR3 activation [66]. CD36 is a sensor of diacylated lipopeptides recognised by TLR2/TLR6 [67]. NAD(P)H oxidase 4 (Nox4) modulates the production of LPS-induced reactive oxygen species (ROS) by interacting with the cytoplasmic TIR domain of TLR4 [68, 69]. TLRs also cooperate with other families of receptors to recognise microbial ligands. TLR2 was shown to collaborate with dectin-1 in zymosan recognition [70] or with the macrophage receptor with collagenous structure (MARCO) in addition to CD14 to respond to TDM, a cell wall glycolipid from Mycobacterium tuberculosis [71]. Collectively these data point to specific and complex mechanisms at the basis of PAMP recognition, highlighted by the requirement of a number of distinct coreceptors and accessory molecules for individual ligands. 
3.1.2. Endogenous Ligand Recognition by TLRs. No crystal structures of TLR-endogenous ligand complexes have been reported so far. Most of the proposed endogenous TLR activators have been shown to form complexes with TLRs in vitro by means of immunoprecipitation assays and functional cell-based assays or in vivo, taking advantage of mice deficient in TLRs or their adaptor proteins. Recently, FRET confocal microscopy and GFP fragment reconstitution have been proposed to study TLR interaction and measure distances between receptors in the range of molecular interactions [72]. This technique might be of great benefit in demonstrating and characterising endogenous ligand recognition by TLRs.

There exists circumstantial evidence that DAMPs and PAMPs may occupy the same or neighbouring binding sites on TLRs. For instance, surfactant protein A was shown to downregulate peptidoglycan and zymosan induced $\mathrm{NF} \kappa \mathrm{B}$ activation and $\mathrm{TNF} \alpha$ secretion by binding to the extracellular domain of TLR2 in RAW 264.7 and alveolar macrophages [73, 74]. However, some DAMPs may utilize different binding sites; whilst the TLR4 mutations D299G and T399I prevent activation by LPS, these polymorphisms confer enhanced ability of TLR4 to respond to fibrinogen [75].

There is also evidence that DAMPs require different coreceptors and accessory molecules to PAMPs. Reviewing the proposed modes of endogenous ligand recognition leads to a rational classification of endogenous molecules based on the receptor, co-receptor(s), and accessory molecule(s) requirement for recognition by $\operatorname{TLR}(\mathrm{s})$ and subsequent cellular activation that is summarized in Figure 2. A first group of DAMPs requires both CD14 and MD-2. This includes both TLR2 and 4 agonists, such as HSP60, HSP70, and biglycan, as well as TLR4 activators such as oxidized LDL and S100 proteins [15, 23, 69, 76, 77]. A second group of DAMPs requires only CD14 as an accessory molecule and these are surfactant protein A and D and lactoferrin [78-80]. A third group comprises DAMPs that have been shown to involve only MD-2 in their recognition by TLRs. Among these, Gp96 and HMGB1 activate TLR2 and 4, whereas fibronectin EDA (FNEDA) and saturated fatty acids activate TLR4 [17, 20, 22, 81-86]. A fourth group includes DAMPs that use co-receptors or accessory molecules different from CD14 and MD-2. Biglycan was recently shown to induce the NLRP3/ASC inflammasome through activation of TLR2/4 and purinergic $\mathrm{P}_{2} \mathrm{X}_{4} / \mathrm{P} 2 \mathrm{X}_{7}$ receptors [87]. Versican-induced responses require TLR2, TLR6, and CD14 [25]. HA dependent TLR4 activation involves CD44 in addition to MD-2 [88]. Autoantibodies against dsDNA and nucleosomes from SLE patients induce DC activation through TLR2 if bound to HMGB1 [89, 90]. Similarly, HMGB1 mediates the activation of plasmacytoid DCs and B cells through TLR9 by DNA-containing immune complexes through a mechanism involving the immunoglobulin superfamily member RAGE [46]. IgG2a-chromatin immune complexes require the synergistic engagement of IgM and TLR9 to activate B cells [31]. TLR7, 8, and TLR9 expressed by $\mathrm{pDCs}$ respond to self-RNA and -DNA respectively when coupled with the endogenous antimicrobial peptide
LL37 [91, 92]. Furthermore, CD32 delivers DNA-containing immune complexes found in serum from SLE patients to intracellular lysosomes containing TLR9, leading to DC activation $[89,90]$. Finally, B cells are activated by DNAor RNA-associated autoantigens by combined B cell antigen receptor (BCR)/TLR9 or TLR7 engagement [93, 94]. This is a provisional list of endogenous activators and their accessory molecules that will certainly expand as we learn more about DAMP-TLR interactions. Collectively, these data indicate that several co-receptors and accessory molecules required for ligand recognition by TLRs are employed by both DAMPs and PAMPs. Further detailed investigation of how DAMPs are recognised by the cell is required to elucidate the precise structural organization of these receptor complexes. A signalling competent conformation of the receptor is required for TLRs to function; however it is not known whether the conformation induced by DAMPs is similar or distinct to that produced by microbial structures where sequential changes in receptor conformation occur upon ligand binding (reviewed in [95]).

3.2. TLR Signalling and Biological Outcomes. Ligand-induced receptor homo- or heterodimerization leads the cytoplasmic signalling domains of TLRs to dimerize. Despite diverse mechanisms of ligand interaction, PAMP-TLR complex crystal studies showed striking similarities in the organization of ligand-TLR dimer complexes that may apply to all TLRs. All three structures feature an " $\mathrm{m}$ "-shaped TLR dimeric architecture in which the C-terminal ends of the TLRs converge and, presumably, cause dimerization of the intracellular domains for signal initiation (reviewed in [97]). The resulting TIR-TIR complex initiates downstream signalling through recruitment of specific adaptor molecules. Five adaptors have been described so far: myeloid differentiation factor 88 (MyD88), MyD88-adaptor like (Mal), TIR domaincontaining adaptor inducing IFN-beta (TRIF), TRIF-related adaptor molecule (TRAM), and sterile alpha and HEATArmadillo motifs (SARM) [98].

Depending on the adaptors recruited to the TLRs, two major intracellular signalling pathways can be activated by TLRs. The first, a MyD88-dependent pathway, is activated by all TLRs except TLR3. It involves the IL-1R-associated kinases (IRAK), IRAK-1 and IRAK-4, TNF receptor-associated factor 6 (TRAF-6), and mitogen-activated kinases (MAPK) and it culminates in the activation of the transcription factor $\mathrm{NF} \kappa \mathrm{B}$ via the IkB kinase (IKK) complex. In turn, $\mathrm{NF} \kappa \mathrm{B}$ mediates the transcription of pro-inflammatory cytokine genes. The second pathway, known as TRIF pathway, is independent of MyD88 and can be activated upon stimulation of TLR3 or 4. It leads to activation of the interferonregulated factors (IRF) family of transcription factors via recruitment of TRIF and results in the synthesis of interferon (IFN).

TLR signalling pathways induced by endogenous molecules in different cell types are poorly investigated, but recent studies report usage of distinct adaptor molecules and induction of distinct signalling pathways downstream of TLRs when stimulated with exogenous or endogenous 

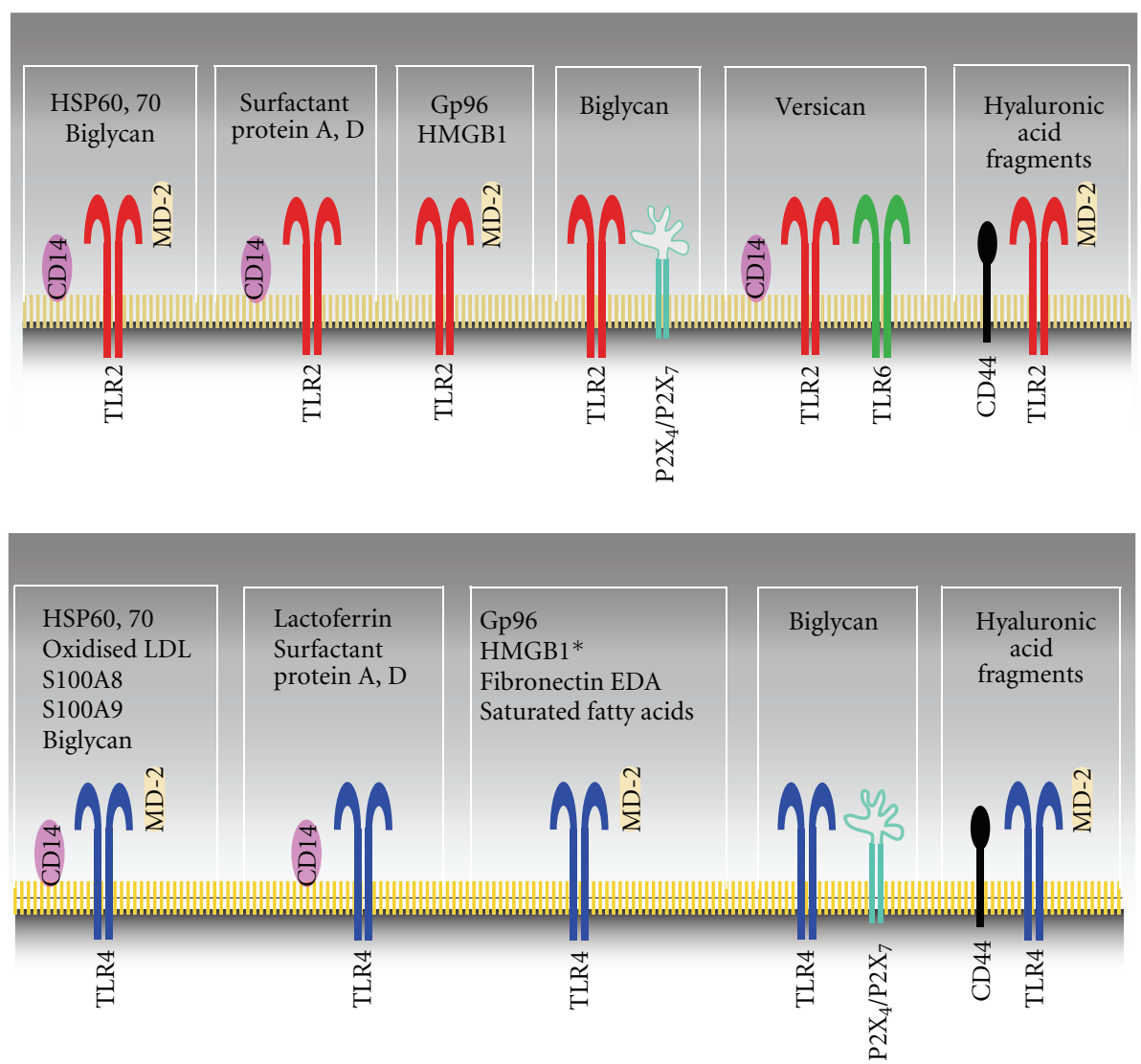

(a)

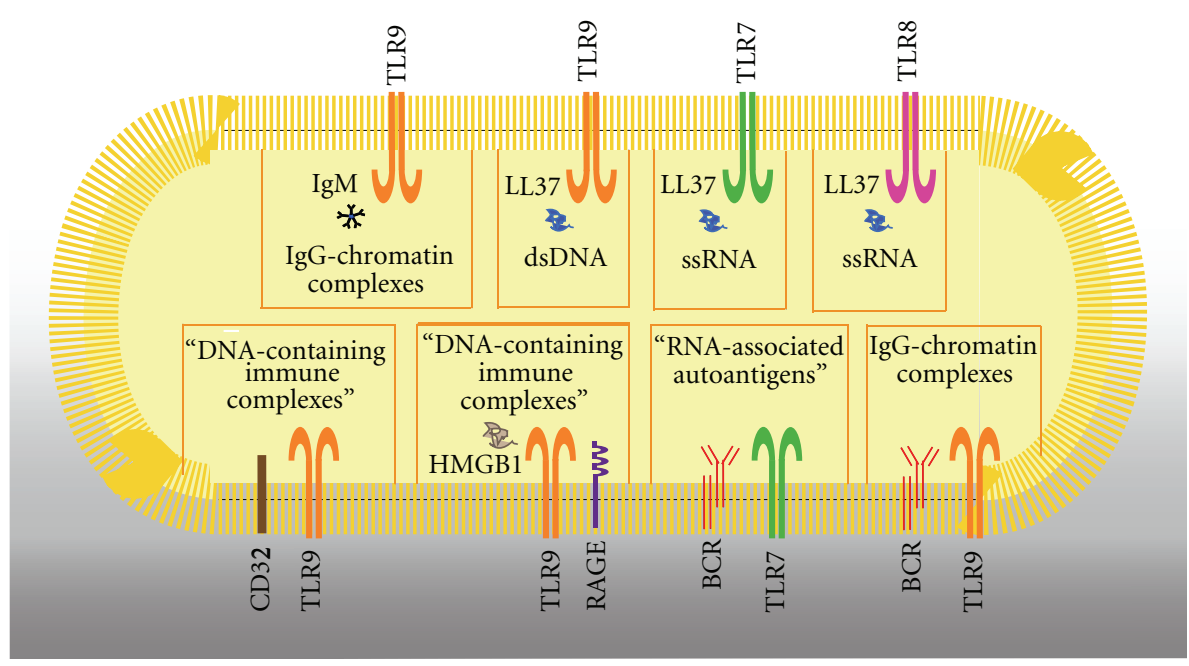

(b)

FIGURE 2: Endogenous ligand recognition by TLRs. The co-receptor(s) and accessory molecule(s) required by DAMPs for recognition by TLR(s) and subsequent cellular activation are shown. (a) TLRs localised on the plasma membrane; (b) TLRs resident in intracellular compartments. $\left.{ }^{*}\right)$ HMGB1 may require MD-2 and CD14 for TLR4 activation (see [96]).

molecules. Activation of TLR4 by LPS can induce both TRIF and MyD88-dependent pathways. In contrast, we have shown that the endogenous TLR4 agonist tenascin-C signals via MyD88 [24]. Similarly, biglycan has been shown to signal through TLR2 and 4 in a MyD88-dependent manner [23].
TLR signalling results in the activation of transcription factors regulating the expression of specific genes whose products trigger various cellular responses. For example, $\mathrm{NF} \kappa \mathrm{B}, \mathrm{AP}-1$, and IRF5 control the expression of genes encoding inflammatory cytokines, whereas IRF3 and IRF7 
induce the expression of type I IFN and IFN-inducible genes. Thus a large number of proteins are synthesised that mediate inflammatory and immune responses and include inflammatory cytokines such as IL-1, IL-6, TNF $\alpha$, IL-12, IFNs, chemokines, adhesion molecules, costimulatory molecules, growth factors, tissue-degrading enzymes such as metalloproteinases, and enzymes that generate inflammatory mediators such as cyclo-oxygenase 2 and inducible nitric oxide synthase (iNOS).

Different microbial agents trigger multiple pathways in different cell types and induce the expression of distinct subset of genes [99-103]. A detailed comparative analysis of the biological outcomes induced by different endogenous versus exogenous TLR molecules has not been performed. However, some crucial differences between host responses to endogenous versus microbial agents are emerging.

HMGB1 and LPS were shown to induce distinct patterns of gene expression in neutrophils. For instance, expression of monoamine oxidase $\mathrm{B}$ and the anti-apoptosis protein Bcl$\mathrm{xl}$ was increased in neutrophils by HMGB1 but not by LPS. Furthermore, whilst the cytokine expression profile induced by HMGB1 versus LPS was similar, a slower induction of TNF $\alpha$ mRNA occurred upon LPS stimulation compared to HMGB1 [20, 104, 105]. HSP60 and LPS, in addition to synergistically enhancing IL-12p40 and IFN $\gamma$ production in murine macrophages and in mHSP60-expressing COS1 cells, were shown to differentially activate APC function. Indeed, only HSP60 was able to stimulate the production of IFN $\alpha$ in peritoneal macrophages and bone marrow-derived DCs and IFN $\alpha$ release was not further increased by HSP60/LPS complexes [43]. Hyaluronan fragments generated following injury were reported to induce inflammatory responses distinct from LPS. A microarray analysis performed on the mouse alveolar macrophage cell line (MH-S) generated a list of genes that respond differently to hyaluronan and LPS. For instance, MMP13, TGF- $\beta 2$, SOCS3, and other genes were induced exclusively by hyaluronan. There were also major differences in the cytokine profile induced. While some cytokines including TNF $\alpha, \mathrm{MCP}-1$, and RANTES were equally induced by both ligands, others, such as granulocyte macrophage-colony stimulating factor (GMCSF), granulocyte colony-stimulating factor (G-CSF), and IL- $1 \alpha$, were significantly different [88]. We have shown that tenascin-C stimulated pro-inflammatory cytokine synthesis in primary human macrophages and synovial fibroblasts in a cell type specific manner, which was significantly different from LPS. Tenascin-C dose dependently induced TNF $\alpha$, IL6 , and IL-8 production in human macrophages. However, it only induced IL-6 synthesis in synovial fibroblasts, whereas LPS induced both IL-6 and IL-8 [24]. Further investigation is required to fully define the differences in signalling pathways and gene expression induced by endogenous versus exogenous TLR activators.

\section{DAMPs and Disease}

DAMPs are key danger signals that alert the organism to tissue damage and initiate the process of tissue repair.
However, in addition to this physiological role in the response to tissue injury, there is evidence which indicates that endogenous TLR activators also contribute to the pathogenesis of many inflammatory and autoimmune diseases that are characterized by aberrant TLR activation.

4.1. High Levels of DAMPs Are Associated with Human Inflammatory Disease. The etiology of many inflammatory and autoimmune diseases is unclear; the initiating stimuli are often not well defined and the reasons why the mechanisms that ordinarily control the immune response fail are not known. However, it is clear that these diseases are characterized by an extremely destructive tissue environment. Accordingly, high levels of DAMPs occur locally and/or systemically in many of these conditions. For example, a wide range of endogenous TLR activators, including heat shock proteins, HMGB1, host DNA, fibrinogen, FNEDA, and tenascin-C, are observed in synovia of RA patients but not in synovia from normal joints or noninflamed synovia from osteoarthritis (OA) patients [106112]. High levels of HMGB1 and tenascin-C circulate in the serum of septic patients $[113,114]$, and high serum concentrations of DNA-containing immune complexes are associated with SLE [46], including nucleosome-HMGB1 complexes $[90,115]$. In addition, elevated levels of low MW HA fragments are reported in the bronchial alveolar lavage fluid and serum of patients with inflammatory lung diseases [116-118]. In many cases levels of endogenous TLR activators are indicative of disease activity; elevated levels of extracellular HMGB1 localize specifically to active lesions of multiple sclerosis (MS) patients and correlate with active inflammation [119]. Furthermore, the S100 family of calcium binding proteins have long been reliable biomarkers of inflammation in a wide variety of diseases; for example, both MRP8 and MRP14 levels in the RA synovium and synovial fluid correlate with disease activity to a degree greater than levels of C-reactive protein (reviewed in [120]). Many endogenous TLR activators are also overexpressed in tumor cells. Figure 3 summarises some of the diseases with which endogenous TLR activators are associated.

4.2. Administration of Exogenous DAMPs Induces Inflammation In Vivo. Further support of a role for endogenous TLR activators in driving disease derives from in vivo studies using experimental models of inflammatory disease. Levels of many DAMPs are elevated during the pathogenesis of numerous diseases in rodent models. In addition, delivery of exogenous DAMPs promotes inflammation in vivo via activation of TLRs. Intra-articular injection of the TLR4 activators FNEDA or tenascin-C induces joint inflammation in wild type but not in TLR4 null mice [24, 86]. Systemic injection of HS causes lethal sepsis, similar to that induced by LPS or zymosan, in wild type but not in TLR4 null mice [121]. Furthermore, DNA released from necrotic hepatocytes stimulates cytokine synthesis via activation of TLR9 during murine acetaminophen-induced liver injury [122]. These and other studies are summarized in Table 1. In addition, 


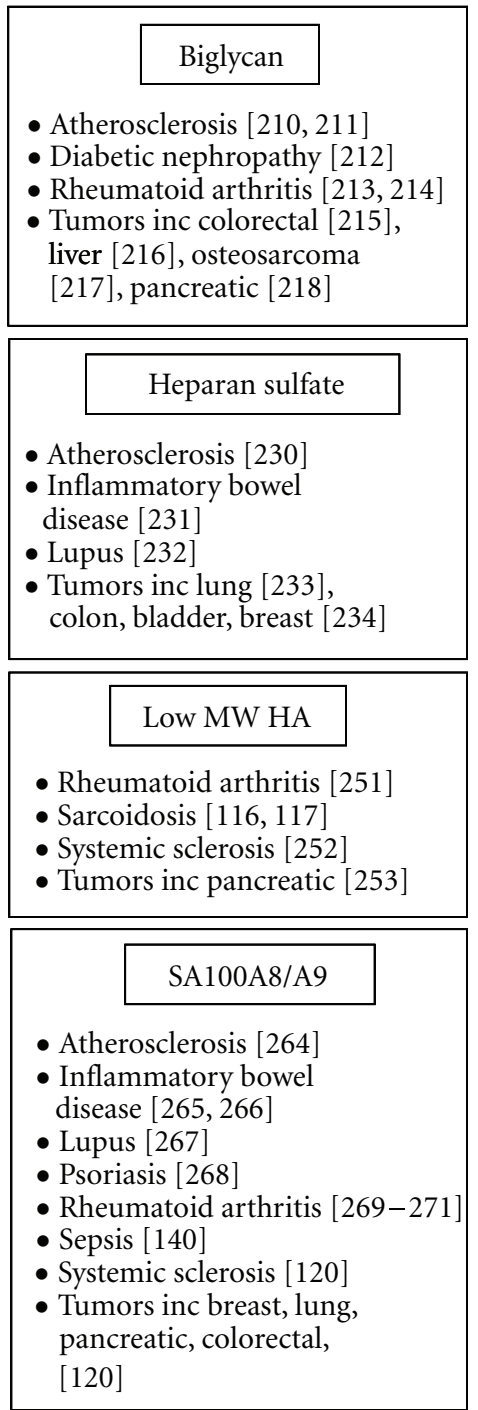

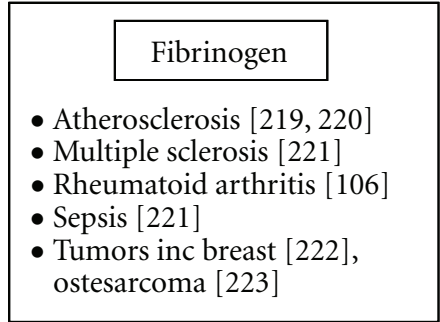

\begin{tabular}{|l|}
\hline \multicolumn{1}{|c|}{ FNEDA } \\
- Atherosclerosis [224] \\
- Psoriasis [225, 226] \\
- Rheumatoid arthritis [110] \\
- Sepsis [227] \\
- Tumors inc liver, lung, \\
colon [228, 229]
\end{tabular}

Figure 3: DAMPs and human disease. High levels of many DAMPs are associated with a wide variety of inflammatory and autoimmune diseases as well as with atherosclerosis and cancer.

many DAMPs can act as adjuvants; this has recently been comprehensively reviewed by Kono and Rock [6]. For example, purified genomic dsDNA boosted both antibody and CD8+ $\mathrm{T}$ cell responses in mice when injected with antigen [123]. Likewise lactoferrin, defensins, low MW HA, and HMGB1 all exhibit adjuvant properties in vivo [124127]. Together these data show that many endogenous TLR activators exhibit pro-inflammatory properties in vivo.

\subsection{Inhibition of DAMP Action In Vivo Ameliorates Dis-} ease. Whilst many DAMPs can induce TLR dependent inflammation in vivo, this does not necessarily demonstrate that these molecules are important in the progression of disease. This evidence has come from mice that do not express specific endogenous TLR activators (Table 2) and studies showing that inhibition of DAMP function can ameliorate disease in vivo (Table 3 ) and we review these data below.
4.3.1. Targeted Deletion of DAMPs Protects from Inflammatory Disease. Biglycan null mice have a considerable survival benefit in LPS-induced sepsis due to reduced TLR2 and 4 dependent cytokine synthesis, cellular infiltration into tissues [23], and lower levels of active caspase-1 and mature IL-1 $\beta$ in the kidney, lung, and circulation [87]. We have shown that tenascin- $\mathrm{C}$ null mice are protected from persistent joint inflammation and tissue destruction during antigen-induced arthritis [24]. In addition, mice lacking MRP8/MRP14 complexes are protected from endotoxin-induced lethal shock and E. coli-induced abdominal sepsis [140, 143] and exhibit reduced lesion volume, brain swelling, and inflammatory cell infiltration during cerebral ischemia [142]. Furthermore, consistent with their enhanced expression during myocardial infarction, mice that lack MRP-8/14 complexes exhibited reduced inflammatory cell infiltration upon experimental arterial injury and attenuated atherosclerotic lesions and macrophage accumulation in plaques compared with mice deficient in apolipoprotein $\mathrm{E}$ alone [141]. 
TABLE 1: DAMPs induce disease in vivo. Administration of DAMPs to rodents either intra-articularly (i.a.), intracerebroventricularly (i.c.), intraperitoneally (i.p.), intratracheally (i.t.), or intravenously (i.v.) can provoke pathological inflammation in vivo.

\begin{tabular}{|c|c|c|c|}
\hline Pathology & DAMP & Effect & Refs \\
\hline Atherosclerosis & Apo CIII-rich VLDL (i.v.) & $\begin{array}{l}\text { Stimulated TLR } 2 \text { dependent monocyte } \\
\text { activation and adhesion }\end{array}$ & {$[128]$} \\
\hline Brain injury & HMGB1 (i.c.) & $\begin{array}{l}\text { Increased cytokines, taste aversion, } \\
\text { fever, mechanical allodynia, promotes } \\
\text { severity of infarction }\end{array}$ & {$[129-131]$} \\
\hline Gut inflammation & HMGB1 (B box) (i.p.) & $\begin{array}{l}\text { Increased ileal mucosal permeability } \\
\text { and bacterial translocation to } \\
\text { mesenteric lymph nodes }\end{array}$ & {$[132]$} \\
\hline \multirow[t]{3}{*}{ Joint disease } & FNEDA (i.a.) & $\begin{array}{l}\text { Induced TLR4 dependent transient } \\
\text { ankle swelling, cytokine synthesis, } \\
\text { synovial inflammation }\end{array}$ & {$[86]$} \\
\hline & HMGB1 (i.a.) & $\begin{array}{l}\text { Induced synovial inflammation, some } \\
\text { pannus formation }\end{array}$ & {$[133]$} \\
\hline & Tenascin-C (i.a.) & $\begin{array}{l}\text { Induced TLR } 4 \text { dependent joint } \\
\text { inflammation and tissue erosion }\end{array}$ & {$[24]$} \\
\hline \multirow[t]{2}{*}{ Liver injury } & DNA & $\begin{array}{l}\text { During acetaminophen induced cell } \\
\text { death induced TLR9 dependent tissue } \\
\text { injury }\end{array}$ & {$[134]$} \\
\hline & HMGB-1 (i.p.) & $\begin{array}{l}\text { Aggravated ischemic reperfusion } \\
\text { injury }\end{array}$ & {$[135]$} \\
\hline Lung injury & HMGB-1 (i.t.) & $\begin{array}{l}\text { Stimulated acute inflammatory injury, } \\
\text { neutrophil accumulation, edema, } \\
\text { cytokine production }\end{array}$ & {$[136-138]$} \\
\hline \multirow{2}{*}{ Sepsis } & HS (i.p.) & Induced TLR4 dependent lethality & {$[121]$} \\
\hline & HMGB1 (i.p.) & $\begin{array}{l}\text { Induced partially TLR } 4 \text { dependent } \\
\text { lethality }\end{array}$ & {$[114]$} \\
\hline
\end{tabular}

TABLE 2: Targeted deletion of DAMPs protects from experimental disease. Mice which do not express certain DAMPs exhibit reduced symptoms of inflammatory disease or tumor metastasis in vivo.

\begin{tabular}{|c|c|c|c|}
\hline DAMP & Disease Model & Effect of deletion & Refs \\
\hline \multirow[t]{2}{*}{ Biglycan } & $\begin{array}{l}\text { Renal inflammation (unilateral } \\
\text { ureteral obstruction) }\end{array}$ & Reduced kidney damage & {$[87]$} \\
\hline & Sepsis (LPS or zymosan) & Protected from lethality & {$[23,87]$} \\
\hline FNEDA & $\begin{array}{l}\text { Atherosclerosis (Apo E deficient, } \\
\text { high fat diet) }\end{array}$ & $\begin{array}{l}\text { Reduced lesion size, number and } \\
\text { macrophage infiltration }\end{array}$ & {$[139]$} \\
\hline \multirow{6}{*}{ MRP8/MRP14 } & Abdominal sepsis (E. coli) & $\begin{array}{l}\text { Reduced bacterial dissemination, } \\
\text { systemic inflammation, liver damage }\end{array}$ & {$[140]$} \\
\hline & $\begin{array}{l}\text { Arterial injury (femoral wire } \\
\text { insertion) }\end{array}$ & $\begin{array}{l}\text { Reduced inflammatory cell infiltration } \\
\text { and neotintimal formation }\end{array}$ & {$[141]$} \\
\hline & $\begin{array}{l}\text { Atherosclerosis (Apo E deficient, } \\
\text { high fat diet) }\end{array}$ & $\begin{array}{l}\text { Attenuated atherosclerotic lesions and } \\
\text { macrophage accumulation in plaques }\end{array}$ & {$[141]$} \\
\hline & $\begin{array}{l}\text { Cerebral ischemia (cerebral } \\
\text { artery occlusion) }\end{array}$ & $\begin{array}{l}\text { Reduced lesion volume, brain swelling } \\
\text { and inflammatory cell infiltration }\end{array}$ & {$[142]$} \\
\hline & Lethal sepsis (LPS ) & Protects from lethality & {$[143]$} \\
\hline & Vasculitis (cytokine induced) & $\begin{array}{l}\text { Reduced neutrophil accumulation and } \\
\text { lesion severity }\end{array}$ & {$[141]$} \\
\hline \multirow[t]{2}{*}{ Tenascin-C } & $\begin{array}{l}\text { Destructive joint inflammation } \\
\text { (antigen induced arthritis) }\end{array}$ & $\begin{array}{l}\text { Protected from joint erosion and tissue } \\
\text { destruction }\end{array}$ & {$[24]$} \\
\hline & $\begin{array}{l}\text { Tumorigenesis (cross with } \\
\text { MMTV/PyV mice) }\end{array}$ & Induced smaller tumor nests & {$[144]$} \\
\hline
\end{tabular}


TABLE 3: Manipulation of DAMP function ameliorates experimental disease. Therapeutic blockade of DAMP function, for example, using monoclonal or polyclonal antibodies (mAb, pAb) or specific inhibitors or silencing DAMP expression by siRNA can reduce disease progression in vivo.

\begin{tabular}{|c|c|c|c|}
\hline DAMP & Disease Model & Mechanism of blockade & Refs \\
\hline \multirow[t]{2}{*}{ HA } & $\begin{array}{l}\text { Lung inflammation } \\
\text { (bleomycin) }\end{array}$ & $\begin{array}{l}\text { Over expression of HA synthase improved } \\
\text { survival and decreased apoptosis }\end{array}$ & {$[145]$} \\
\hline & Sepsis (LPS) & $\begin{array}{l}\text { High MW HA reduced lung neutrophil } \\
\text { infiltration and cytokine synthesis }\end{array}$ & {$[146]$} \\
\hline \multirow{13}{*}{ HMGB1 } & $\begin{array}{l}\text { Brain injury (transient } \\
\text { ischemia) }\end{array}$ & $\begin{array}{l}\text { mAb reduced infarct size and severity, } \\
\text { locomotor function, cytokine synthesis }\end{array}$ & {$[130]$} \\
\hline & Colitis (DSS, TNBS) & $\begin{array}{l}\text { pAb, ethyl pyruvate ameliorated disease, } \\
\text { reduced cytokine synthesis, associated } \\
\text { tumors }\end{array}$ & {$[147,148]$} \\
\hline & Lung inflammation (LPS) & pAb decreased neutrophils, lung edema & {$[136,138]$} \\
\hline & Lung injury (ventilator) & $\begin{array}{l}\text { Ab improved oxygenation, neutrophil influx, } \\
\text { cytokine synthesis }\end{array}$ & {$[149]$} \\
\hline & $\begin{array}{l}\text { Hepatic ischemia } \\
\text { reperfusion injury }\end{array}$ & pAb decreased liver damage & {$[135]$} \\
\hline & $\begin{array}{l}\text { Acute pancreatitis (duodenal } \\
\text { loop closure) }\end{array}$ & $\begin{array}{l}\text { pAb improved pancreas and lung damage, } \\
\text { aggravated bacterial translocation to pancreas }\end{array}$ & {$[150]$} \\
\hline & $\begin{array}{l}\text { Hemorrhagic shock (blood } \\
\text { withdrawal) }\end{array}$ & $\begin{array}{l}\text { pAb improved survival, ameliorated ileal } \\
\text { permeability, decreased serum cytokines }\end{array}$ & {$[151]$} \\
\hline & $\begin{array}{l}\text { Hemorrhagic lung injury } \\
\text { (cyclo-phosphamide) }\end{array}$ & $\begin{array}{l}\text { pAb reduced pulmonary edema, neutrophil } \\
\text { accumulation, lung permeability }\end{array}$ & {$[152]$} \\
\hline & \multirow{4}{*}{$\begin{array}{l}\text { Sepsis (LPS, E. Coli, cecal } \\
\text { ligation and puncture) }\end{array}$} & $\begin{array}{l}\mathrm{pAb}, \mathrm{mAb}, \mathrm{DNA} \text { binding box A protected } \\
\text { from/reversed lethality, rescues taste aversion }\end{array}$ & {$[114,129,153-155]$} \\
\hline & & $\begin{array}{l}\text { Ethyl pyruvate, stearoyl } \\
\text { lysophosphatidylcholine, nicotine (inhibit } \\
\text { secretion) protected from lethality }\end{array}$ & {$[156-158]$} \\
\hline & & $\begin{array}{l}\text { Neural ant-inflammatory peptides vasoactive } \\
\text { intestinal peptide and urocortin rescue } \\
\text { lethality }\end{array}$ & {$[159]$} \\
\hline & & $\begin{array}{l}\text { Cisplatin (nuclear sequestration of HMGB1) } \\
\text { protected from lethality }\end{array}$ & {$[160]$} \\
\hline & $\begin{array}{l}\text { Rheumatoid arthritis } \\
\text { (Collagen) }\end{array}$ & $\begin{array}{l}\text { pAb, DNA binding box A reduced severity of } \\
\text { established joint disease }\end{array}$ & {$[161]$} \\
\hline \multirow[t]{2}{*}{ HSP90 } & $\begin{array}{l}\text { Rheumatoid arthritis } \\
\text { (Collagen, adjuvant) }\end{array}$ & $\begin{array}{l}\text { SNX-7081 (inhibitor) ameliorated disease, } \\
\text { joints returned to normal }\end{array}$ & {$[162]$} \\
\hline & Tumorigenesis (nude mice) & BX-2819 (inhibitor) inhibited tumor growth & [163] \\
\hline \multirow{4}{*}{ Neutrophil elastase } & $\begin{array}{l}\text { Acute lung injury (LPS } \\
\text { induced) }\end{array}$ & $\begin{array}{l}\text { Sivelestat or L-658,758 (inhibitors) reduced } \\
\text { HMGB levels and lung damage }\end{array}$ & {$[164,165]$} \\
\hline & Colitis (dextran) & $\begin{array}{l}\text { ONO-5046 (inhibitor) reduced disease } \\
\text { severity }\end{array}$ & {$[166]$} \\
\hline & $\begin{array}{l}\text { Rheumatoid arthritis } \\
\text { (Collagen) }\end{array}$ & $\begin{array}{l}\text { ONO-5046 (inhibitor) reduced incidence } \\
\text { and severity of disease, ablated cartilage } \\
\text { destruction }\end{array}$ & {$[167]$} \\
\hline & $\begin{array}{l}\text { Hepatic ischemia } \\
\text { reperfusion injury }\end{array}$ & $\begin{array}{l}\text { GW311616A (inhibitor) ameliorated liver } \\
\text { damage, decreased neutrophil infiltration }\end{array}$ & {$[168]$} \\
\hline Serum amyloid A & $\begin{array}{l}\text { Tumorigenesis (LLC } \\
\text { inoculation) }\end{array}$ & $\mathrm{pAb}$ reduced lung metastasis & {$[169]$} \\
\hline Versican & $\begin{array}{l}\text { Tumorigenesis (LLC } \\
\text { inoculation) }\end{array}$ & siRNA reduced lung metastasis & {$[25]$} \\
\hline
\end{tabular}


4.3.2. DAMP Antagonists Ameliorate Disease. The fact that blockade of DAMP function ameliorates disease in vivo further supports a role for endogenous TLR activators in inflammatory disease. The best example of how this can be achieved is with HMGB1 (reviewed in [170-174]), although manipulation of other DAMPs including HA, neutrophil elastase (NE), and versican can all protect against disease (Table 3). DAMPs comprise an enormously diverse subset of molecules. As such there exists a number of different mechanisms to prevent their inflammatory action, some of which are described below.

(i) Blockade of TLR Activation. One strategy that has proved effective is to manipulate the function of individual DAMPs by preventing TLR activation at the cell surface. Administration of polyclonal anti-HMGB1 antibodies or the DNA-binding A box of HMGB1, a competitive inhibitor of the pro-inflammatory B box, can reverse the lethality of established sepsis $[114,153,154]$ and ameliorate collageninduced arthritis in rodents (reviewed in [161]). However, whilst some reports demonstrate that monoclonal antiHMGB1 antibodies are efficacious preventing organ damage in experimental models of sepsis [155], others suggest that monoclonal antibodies are not effective in suppressing arthritic disease in vivo [175]. This may be due to the multivalent nature of the mode of action of HMGB1. One alternative approach may be to use synthetic, bent oligonucleotides that have a high affinity for HMGB1, and suppress HMGB1-induced proliferation and migration of smooth muscle cells in vitro [176]. Another approach may be the use of an engineered mutant fragment, HMGB1 Mut (102-105) carrying two glycine substitutions, that decreased TNF $\alpha$ release induced by the full-length HMGB1 protein in human monocyte cultures [177]. In addition, the N-terminal domain of thrombomodulin, an endothelial anticoagulant cofactor, exerts anti-inflammatory effects in a model of lethal endotoxemia partly by binding to and sequestering HMGB1 [178].

(ii) Prevention of DAMP Accumulation. DAMPs can be generated by release from necrotic cells, secretion from activated cells, cleavage of larger molecules, or specific upregulation upon tissue injury. Manipulation of tissue levels of DAMPs may provide another window of therapeutic opportunity. Indeed, ethyl pyruvate, stearoyl lysophosphatidylcholine, and nicotine have been shown to be efficacious in ameliorating experimental sepsis by preventing HMGB1 release during experimental sepsis [156-158]. However, the mechanism by which they do so is unclear and these compounds are likely also to affect numerous other cell processes. HMGB1 is released from cells by two distinct mechanisms: it is liberated from cells undergoing necrosis [179], or it is hyperacetylated and then actively secreted from stimulated cells. This nonclassical secretion pathway is distinct from the passage through the ER and Golgi taken by signal tagged proteins, instead requiring the microtubule cytoskeleton [180]. Other DAMPs including the S100 proteins are also secreted in the same way [181] and targeting this pathway therefore may potentially offer a means to modulate the release of intracellular DAMPs.

One class of DAMPs comprises ECM fragments generated by release from intact matrices. Inhibition of this process has been demonstrated; for example, release of immunestimulatory $\mathrm{HS}$ fragments from the ECM in vivo can be mediated by the proteolytic action of elastase [182]. Injection of elastase into the peritoneal cavity of mice caused the release of HS and induced sepsis, nearly as effectively as direct injection of HS or LPS [121]. Thus therapeutic measures aimed at blocking elastase could reduce the production of endogenous TLR4 activators. Indeed, pre-treatment with NE inhibitor before induction of hepatic ischemia-reperfusion injury ameliorated liver damage [168]. HS fragments are also generated upon ECM oxidation by reactive oxygen species (ROS). Extracellular superoxide dismutase (EC-SOD) is an antioxidant enzyme that protects the lung from oxidantmediated inflammation. One way in which it does this is to protect HS from oxidative fragmentation; bronchoalveolar lavage fluid from EC-SOD knockout mice after asbestos exposure showed increased HS shedding from the lung parenchyma [183]. An alternative strategy may be to alter the balance of immune-silent intact ECM molecules versus immune-stimulatory fragments either directly or indirectly. Specific over expression of high MW HA in the lung has been achieved using transgenic mice that constitutively express HA synthase. These mice showed that improved survival and decreased apoptosis during bleomycin induce lung inflammation [145].

Finally, for DAMPs whose expression is specifically upregulated during inflammation it may be possible to manipulate this induction of expression. Indeed, knockdown of versican expression in Lewis lung carcinoma cell lines (LLC) ablated their tumorigenic capability, promoting mouse survival and reduced metastasis, whilst overexpression of versican in LLC lines with low innate metastatic potential increased lung metastasis [25].

Together these data indicate that endogenous TLR activators significantly contribute to driving inflammatory disease in vivo and suggest that targeting this method of TLR activation may potentially be of therapeutic value in combating disease.

\section{Conclusions and Perspectives: Targeting DAMPs in the Clinic?}

Current strategies in clinical development for TLR blockade include (1) global blockade of individual TLR function using neutralizing antibodies, soluble TLR extracellular domains (ECDs), natural antagonists, and small molecule inhibitors, (2) inhibition of signalling pathways-activated downstream of TLR stimulation using small molecules to target MyD88/TRAF/IRAK complex formation, MAPK, or IKK activity, or (3) using PAMP antagonists such as LPS inhibitors. Some of these compounds have reached phase II clinical trials and the results are currently awaited, whilst others, particularly those targeting common signalling pathways such as MAPK, have proved to be of limited efficacy (reviewed in [11]). 
Suppressing DAMP activation of TLRs offers a host of new potential targets for treating inflammatory diseases that may be viable alternatives to current approaches. Evidence that blockade of these mediators can ameliorate disease in human studies is beginning to emerge. Hyaluronate improves pain and prostaglandin E (PGE) levels in patients with RA [184], transfer of HSP-specific regulatory T cells inhibits inflammation in animal models of arthritis and exhibited promising results in preliminary clinical trials [185], HMGB1 antibodies prevent the activation of cells by serum from SLE patients [46], and the neutrophil elastase inhibitor sivelestat improves the mortality rate of patients with sepsis $[186,187]$. By carefully choosing a target unique to the response to tissue damage, and not to pathogen mediated activation of the immune response, this strategy may have the additional advantage of leaving the host response to infection intact. Given the evidence that supports the idea that distinct molecular machinery is required for DAMP activation of TLRs, another strategy would be to block co-receptors or accessory molecules essential for DAMP activation. In addition a comparative analysis of adaptors, kinases, and transcription factors involved in signalling activated by DAMPs versus PAMPs may highlight key differences that, if selectively targeted, could lead to specific therapies engineered to silence danger signals without compromising the host immune defence.

We have highlighted here the possible levels of intervention in DAMP activation of TLR-mediated inflammation, namely, manipulating DAMP activation of TLRs or controlling tissue level of DAMPs. Whilst these strategies are efficacious in preventing experimental disease, there is also evidence that preconditioning with DAMPs can have the same effect. Administration of small doses of HMGB1 one hour prior to induction of hepatic reperfusion injury protected from liver damage and reduced serum TNF $\alpha$ and IL-6 levels via inhibition of TLR4 signalling $[188,189]$ and lactoferrin can protect from lethal E.coli injection [190].

It is apparent that low tissue levels of DAMPs are beneficial during tissue repair to induce a resolvable, physiological immune response. In contrast, high levels of DAMPs are generated during chronic inflammation. We propose a situation where a damage chain reaction occurs: increasing levels of pro-inflammatory DAMPs create more tissue damage which significantly amplifies the tissue levels of DAMPs which go on to create yet more tissue damage ad infinitum. These tissue levels of DAMPs become harmful and mediate a non-resolving perpetual inflammatory state (Figure 4). Thus targeting DAMP-mediated activation of TLRs may block this chronic inflammatory loop, although it will be important to assess whether total blockade of DAMP function will compromise tissue repair to any deleterious extent.

In addition, in the destructive milieu that occurs during inflammatory disease there are likely to be high levels of many DAMPs. Working out which are keys to disease pathogenesis may not be a trivial matter, and combinations of inhibitors may be needed to successfully dampen down endogenously driven inflammation. Alternatively, hierarchies may exist amongst DAMPs such as those that exist for

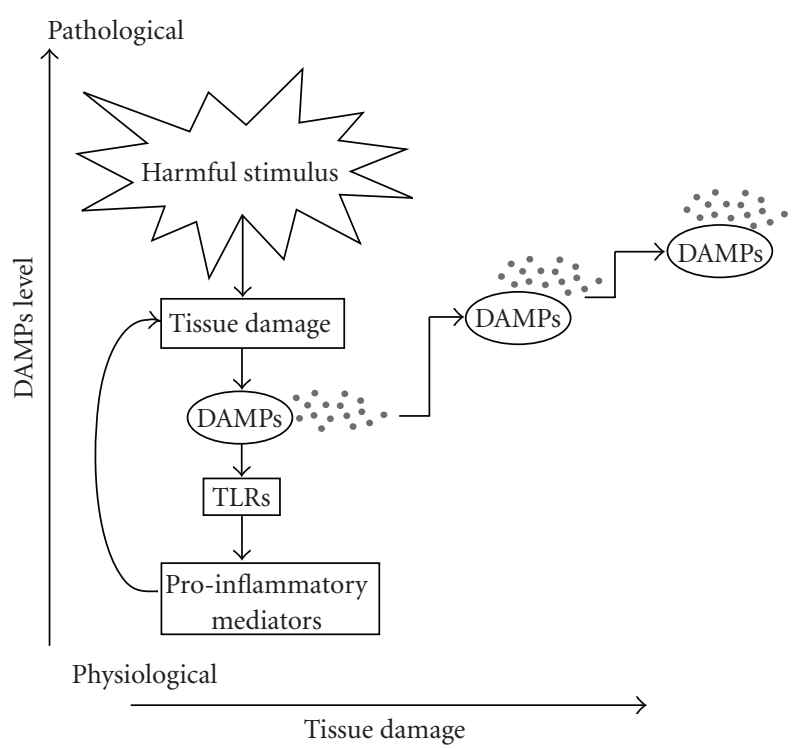

FIGURE 4: The "damage chain reaction." Harmful stimuli, including pathogens, injury, heat, autoantigens, tumor, and necrotic cells, cause tissue damage. Endogenous danger signals are generated and induce a pro-inflammatory cascade by activating TLRs. In turn, pro-inflammatory mediators are upregulated and trigger further tissue damage leading to increasing DAMPs levels. Thus a vicious cycle is sustained and may result in chronic inflammation and autoimmunity.

inflammatory cytokines, for example, where TNF $\alpha$ induces a cascade of cytokine synthesis. Indeed, low MW HA induces $\beta$-defensin 2 via TLR2 and 4 activation in murine keratinocytes ex vivo and in vivo [191]. These DAMPs may be key targets to prevent the induction of an autocrine loop of inflammation. Unravelling potential hierarchies amongst DAMPs represents a major challenge for future investigations. These may be aided by approaches such as microarray and deep sequencing technologies, as well as proteomewide screening, to enable the comparison of the global effects of different DAMPs on inflammatory gene expression. Likewise, examining the stimuli that induce DAMP expression or release upon tissue injury will be important in establishing a "chain of command" of DAMP action. In parallel, the development of validated reagents and tools which serve to ablate the expression or function of individual DAMPS will yield key information about redundancy and co-dependency.

The threshold of DAMP(s) required to induce disease may vary upon the duration and degree of host tissue damage. However, current knowledge about the kinetics of expression or release of DAMPs and their turnover during disease progression is limited. Indeed, on one hand, validated commercial assays for measuring various endogenous danger signals are often unavailable or prohibitively expensive. On the other hand, access to patient specimens and pathological data is in many cases restricted. Thus, the correlation between degree of tissue damage and levels of DAMP(s) is either unknown or limited to small sample size, often representative of end stage of disease. The threshold of 
DAMPs required to trigger chronic inflammation may also depend on a variety of host genetic factors, including singlenucleotide polymorphisms (SNPs), which can affect how humans respond to injury and develop disease. Examining the role of DAMPs within the context of different genetic backgrounds will also be key to dissecting out their role in inflammatory disease. The use of larger patient sample sizes including diverse genetic populations and a befitting proportion of male and females will be vital. In addition, the development of mouse strains with much greater DNA diversity than strains traditionally employed [192] may provide mice with combinations of different traits that more closely reflect the genomic variations of humans in preclinical studies. We expect that the next few years will provide a much more concrete picture of how DAMPs link tissue damage to chronic inflammation as an increasing number of tools become available.

Finally, a normal wound healing response does not typically lead to chronic inflammation. This is, in part, because a number of mechanisms exist to negatively regulate TLR activation. These include the release of soluble decoy TLR receptors, intracellular inhibitory molecules such as IRAKM, SOCS1, Tam family kinases, and transmembrane regulators such as SIGIRR (reviewed in [8, 193]). Viruses have also evolved mechanisms to target adapters in TLR signalling: A46R from vaccinia virus, which sequesters MyD88, Mal, Trif, and Tram [194], and NS3/4A from hepatitis C virus, which degrades Trif [195]. In addition, recently, microRNA, miR-147, whose expression is induced upon stimulation of multiple TLRs, was shown to attenuate TLR stimulationinduced-inflammatory response in macrophages [196].

However, these pathways do not appear to discriminate between distinct methods of TLR stimulation and act on DAMP- and PAMP-mediated activation alike. Chen et al. recently identified one way in which specific activation of TLRs by DAMPs, but not PAMPs, may be inhibited (reviewed in [197]). CD24, or heat stable antigen, is a GPI anchored protein that binds to DAMPs such as HMGB1, hsp70, and hsp90 in order to suppress their activation of inflammatory signalling pathways. CD24 null mice exhibit increased susceptibility to DAMP-, but not PAMP, induced inflammation. This is mediated at least in part through CD24 association with Siglec-10/G causing activation of associated phosphatases which are proposed to repress DAMP-initiated signalling. Dysfunction of this pathway might contribute to the etiology of autoimmune diseases and likewise may offer a means to selectively inhibit DAMP activity [198]. In addition, sTLR2 can blunt immune responses without preventing microbial recognition: mice injected with Gram positive bacteria together with sTLR2 exhibited reduced inflammatory cytokine levels and cell migration but this did not compromise their ability to clear live Gram-positive bacteria-induced infection [199]. As such enhancing naturally suppressive mechanisms may also be a viable strategy for reducing inflammation.

Thus DAMPs appear to be a double-edged sword. While being vital for tissue repair, they also play a role in the pathogenesis of many inflammatory and autoimmune diseases that feature aberrant TLR activation. In these diseases harmful stimuli cause tissue damage; in an attempt of tissue healing, inflammatory responses are initiated and generate DAMPs that induce an autocrine loop of inflammation. Understanding why the natural mechanisms that keep DAMP-mediated inflammation in check fail in disease, as well as dissecting out which mechanisms of TLR activation and signalling are unique to DAMPs, may enlighten our approach to engineering targeted and efficacious therapies designed to dampen inflammation.

\section{Acknowledgments}

The authors are supported by the Arthritis Research Campaign and a Medical Research Council New Investigators Research Grant. They thank Professor Nick Gay and Dr. Nikki Horwood for critically reading this manuscript.

\section{References}

[1] P. Matzinger, "Tolerance, danger, and the extended family," Annual Review of Immunology, vol. 12, pp. 991-1045, 1994.

[2] B. Beutler, "Neo-ligands for innate immune receptors and the etiology of sterile inflammatory disease," Immunological Reviews, vol. 220, no. 1, pp. 113-128, 2007.

[3] M. E. Bianchi, "DAMPs, PAMPs and alarmins: all we need to know about danger," Journal of Leukocyte Biology, vol. 81, no. 1, pp. 1-5, 2007.

[4] S. Gordon, "Pattern recognition receptors: doubling up for the innate immune response," Cell, vol. 111, no. 7, pp. 927930, 2002.

[5] R. Medzhitov and C. A. Janeway Jr., "Decoding the patterns of self and nonself by the innate immune system," Science, vol. 296, no. 5566, pp. 298-300, 2002.

[6] H. Kono and K. L. Rock, "How dying cells alert the immune system to danger," Nature Reviews Immunology, vol. 8, no. 4, pp. 279-289, 2008.

[7] K. Chen, J. Huang, W. Gong, P. Iribarren, N. M. Dunlop, and J. M. Wang, "Toll-like receptors in inflammation, infection and cancer," International Immunopharmacology, vol. 7, no. 10, pp. 1271-1285, 2007.

[8] F. Y. Liew, D. Xu, E. K. Brint, and L. A. J. O'Neill, "Negative regulation of Toll-like receptor-mediated immune responses," Nature Reviews Immunology, vol. 5, no. 6, pp. 446-458, 2005.

[9] M. T. Lotze, H. J. Zeh, A. Rubartelli et al., "The grateful dead: damage-associated molecular pattern molecules and reduction/oxidation regulate immunity," Immunological Reviews, vol. 220, no. 1, pp. 60-81, 2007.

[10] A. Mantovani, "Cancer: inflaming metastasis," Nature, vol. 457, no. 7225, pp. 36-37, 2009.

[11] K. S. Midwood, A. M. Piccinini, and S. Sacre, "Targeting Tolllike receptors in autoimmunity," Current Drug Targets, vol. 10, no. 11, pp. 1139-1155, 2009.

[12] K. Ohashi, V. Burkart, S. Flohé, and H. Kolb, "Cutting edge: heat shock protein 60 is a putative endogenous ligand of the Toll-like receptor-4 complex," Journal of Immunology, vol. 164, no. 2, pp. 558-561, 2000.

[13] S. Basu, R. J. Binder, R. Suto, K. M. Anderson, and P. K. Srivastava, "Necrotic but not apoptotic cell death releases 
heat shock proteins, which deliver a partial maturation signal to dendritic cells and activate the NF- $\kappa \mathrm{B}$ pathway," International Immunology, vol. 12, no. 11, pp. 1539-1546, 2000.

[14] M. Li, D. F. Carpio, Y. Zheng et al., "An essential role of the NF- $\kappa \mathrm{B} /$ Toll-like receptor pathway in induction of inflammatory and tissue-repair gene expression by necrotic cells," Journal of Immunology, vol. 166, no. 12, pp. 7128-7135, 2001.

[15] A. Asea, M. Rehli, E. Kabingu et al., "Novel signal transduction pathway utilized by extracellular HSP70: role of Toll-like receptor (TLR) 2 and TLR4," Journal of Biological Chemistry, vol. 277, no. 17, pp. 15028-15034, 2002.

[16] R. M. Vabulas, P. Ahmad-Nejad, S. Ghose, C. J. Kirschning, R. D. Issels, and H. Wagner, "HSP70 as endogenous stimulus of the Toll/interleukin-1 receptor signal pathway," Journal of Biological Chemistry, vol. 277, no. 17, pp. 15107-15112, 2002.

[17] R. M. Vabulas, S. Braedel, N. Hilf et al., "The endoplasmic reticulum-resident heat shock protein Gp96 activates dendritic cells via the Toll-like receptor 2/4 pathway," Journal of Biological Chemistry, vol. 277, no. 23, pp. 20847-20853, 2002.

[18] M. F. Roelofs, W. C. Boelens, L. A. B. Joosten et al., "Identification of small heat shock protein B8 (HSP22) as a novel TLR4 ligand and potential involvement in the pathogenesis of rheumatoid arthritis," Journal of Immunology, vol. 176, no. 11, pp. 7021-7027, 2006.

[19] D. S. Wheeler, M. A. Chase, A. P. Senft, S. E. Poynter, H. R. Wong, and K. Page, "Extracellular Hsp72, an endogenous DAMP, is released by virally infected airway epithelial cells and activates neutrophils via Toll-like receptor (TLR)-4," Respiratory Research, vol. 10, p. 31, 2009.

[20] J. S. Park, D. Svetkauskaite, Q. He et al., "Involvement of Tolllike receptors 2 and 4 in cellular activation by high mobility group box 1 protein," Journal of Biological Chemistry, vol. 279, no. 9, pp. 7370-7377, 2004.

[21] J. R. Klune, R. Dhupar, J. Cardinal, T. R. Billiar, and A. Tsung, "HMGB1: endogenous danger signaling," Molecular Medicine, vol. 14, no. 7-8, pp. 476-484, 2008.

[22] J. S. Park, F. Gamboni-Robertson, Q. He et al., "High mobility group box 1 protein interacts with multiple Toll-like receptors," American Journal of Physiology, vol. 290, no. 3, pp. C917-C924, 2006.

[23] L. Schaefer, A. Babelova, E. Kiss et al., "The matrix component biglycan is proinflammatory and signals through Tolllike receptors 4 and 2 in macrophages," Journal of Clinical Investigation, vol. 115, no. 8, pp. 2223-2233, 2005.

[24] K. Midwood, S. Sacre, A. M. Piccinini et al., "Tenascin$\mathrm{C}$ is an endogenous activator of Toll-like receptor 4 that is essential for maintaining inflammation in arthritic joint disease," Nature Medicine, vol. 15, no. 7, pp. 774-780, 2009.

[25] S. Kim, H. Takahashi, W.-W. Lin et al., "Carcinoma-produced factors activate myeloid cells through TLR2 to stimulate metastasis," Nature, vol. 457, no. 7225, pp. 102-106, 2009.

[26] C. Termeer, F. Benedix, J. Sleeman et al., "Oligosaccharides of hyaluronan activate dendritic cells via Toll-like receptor 4," Journal of Experimental Medicine, vol. 195, no. 1, pp. 99-111, 2002.

[27] G. B. Johnson, G. J. Brunn, Y. Kodaira, and J. L. Platt, "Receptor-mediated monitoring of tissue well-being via detection of soluble heparan sulfate by Toll-like receptor 4," Journal of Immunology, vol. 168, no. 10, pp. 5233-5239, 2002.
[28] N. Funderburg, M. M. Lederman, Z. Feng et al., "Human $\beta$-defensin-3 activates professional antigen-presenting cells via Toll-like receptors 1 and 2," Proceedings of the National Academy of Sciences of the United States of America, vol. 104, no. 47, pp. 18631-18635, 2007.

[29] K. Karikó, H. Ni, J. Capodici, M. Lamphier, and D. Weissman, "mRNA is an endogenous ligand for Toll-like receptor 3," Journal of Biological Chemistry, vol. 279, no. 13, pp. 12542-12550, 2004.

[30] J. Vollmer, S. Tluk, C. Schmitz et al., "Immune stimulation mediated by autoantigen binding sites within small nuclear RNAs involves Toll-like receptors 7 and 8," Journal of Experimental Medicine, vol. 202, no. 11, pp. 1575-1585, 2005.

[31] E. A. Leadbetter, I. R. Rifkin, A. M. Hohlbaum, B. C. Beaudette, M. J. Shlomchik, and A. Marshak-Rothstein, "Chromatin-IgG complexes activate B cells by dual engagement of IgM and Toll-like receptors," Nature, vol. 416, no. 6881, pp. 603-607, 2002.

[32] J. Hurst, N. Prinz, M. Lorenz et al., "TLR7 and TLR8 ligands and antiphospholipid antibodies show synergistic effects on the induction of IL-1 $\beta$ and caspase- 1 in monocytes and dendritic cells," Immunobiology, vol. 214, no. 8, pp. 683-691, 2009.

[33] Y. Döring, J. Hurst, M. Lorenz et al., "Human antiphospholipid antibodies induce TNF $\alpha$ in monocytes via Toll-like receptor 8," Immunobiology, vol. 215, no. 3, pp. 230-241, 2010.

[34] N. Satta, S. Dunoyer-Geindre, G. Reber et al., "The role of TLR2 in the inflammatory activation of mouse fibroblasts by human antiphospholipid antibodies," Blood, vol. 109, no. 4, pp. 1507-1514, 2007.

[35] M. J. Mulla, J. J. Brosens, L. W. Chamley et al., "Antiphospholipid antibodies induce a pro-inflammatory response in first trimester trophoblast via the TLR4/MyD88 pathway," American Journal of Reproductive Immunology, vol. 62, no. 2, pp. 96-111, 2009.

[36] S. S. Pierangeli, M. E. Vega-Ostertag, E. Raschi et al., "Tolllike receptor and antiphospholipid mediated thrombosis: in vivo studies," Annals of the Rheumatic Diseases, vol. 66, no. 10, pp. 1327-1333, 2007.

[37] C. Erridge and N. J. Samani, "Saturated fatty acids do not directly stimulate Toll-like receptor signaling," Arteriosclerosis, Thrombosis, and Vascular Biology, vol. 29, no. 11, pp. 1944-1949, 2009.

[38] K.-M. Lee and S.-Y. Seong, "Partial role of TLR4 as a receptor responding to damage-associated molecular pattern," Immunology Letters, vol. 125, no. 1, pp. 31-39, 2009.

[39] K. A. Cavassani, M. Ishii, H. Wen et al., "TLR3 is an endogenous sensor of tissue necrosis during acute inflammatory events," Journal of Experimental Medicine, vol. 205, no. 11, pp. 2609-2621, 2008.

[40] M.-F. Tsan and B. Gao, "Endogenous ligands of Toll-like receptors," Journal of Leukocyte Biology, vol. 76, no. 3, pp. 514-519, 2004.

[41] M.-F. Tsan and B. Gao, "Heat shock proteins and immune system," Journal of Leukocyte Biology, vol. 85, no. 6, pp. 905910, 2009.

[42] M. P. Radsak, N. Hilf, H. Singh-Jasuja et al., "The heat shock protein Gp96 binds to human neutrophils and monocytes and stimulates effector functions," Blood, vol. 101, no. 7, pp. 2810-2815, 2003. 
[43] A. Osterloh, U. Kalinke, S. Weiss, B. Fleischer, and M. Breloer, "Synergistic and differential modulation of immune responses by Hsp60 and lipopolysaccharide," Journal of Biological Chemistry, vol. 282, no. 7, pp. 4669-4680, 2007.

[44] T. Warger, N. Hilf, G. Rechtsteiner et al., "Interaction of TLR2 and TLR4 ligands with the N-terminal domain of Gp96 amplifies innate and adaptive immune responses," Journal of Biological Chemistry, vol. 281, no. 32, pp. 22545-22553, 2006.

[45] C. Habich, K. Kempe, R. Van Der Zee et al., "Heat shock protein 60: specific binding of lipopolysaccharide," Journal of Immunology, vol. 174, no. 3, pp. 1298-1305, 2005.

[46] J. Tian, A. M. Avalos, S.-Y. Mao et al., "Toll-like receptor 9-dependent activation by DNA-containing immune complexes is mediated by HMGB1 and RAGE," Nature Immunology, vol. 8, no. 5, pp. 487-496, 2007.

[47] L. Bandholtz, Y. Guo, C. Palmberg et al., "Hsp90 binds CpG oligonucleotides directly: implications for Hsp90 as a missing link in CpG signaling and recognition," Cellular and Molecular Life Sciences, vol. 60, no. 2, pp. 422-429, 2003.

[48] H. Yanai, T. Ban, Z. Wang et al., "HMGB proteins function as universal sentinels for nucleic-acid-mediated innate immune responses," Nature, vol. 462, no. 7269, pp. 99-103, 2009.

[49] R. Medzhitov, "Toll-like receptors and innate immunity," Nature Reviews Immunology, vol. 1, no. 2, pp. 135-145, 2001.

[50] L. Liu, I. Botos, Y. Wang et al., "Structural basis of Toll-like receptor 3 signaling with double-stranded RNA," Science, vol. 320, no. 5874, pp. 379-381, 2008.

[51] M. S. Jin, S. E. Kim, J. Y. Heo et al., "Crystal structure of the TLR1-TLR2 heterodimer induced by binding of a tri-acylated lipopeptide," Cell, vol. 130, no. 6, pp. 1071-1082, 2007.

[52] H. M. Kim, B. S. Park, J.-I. Kim et al., "Crystal structure of the TLR4-MD-2 complex with bound endotoxin antagonist Eritoran," Cell, vol. 130, no. 5, pp. 906-917, 2007.

[53] B. S. Park, D. H. Song, H. M. Kim, B.-S. Choi, H. Lee, and J.-O. Lee, "The structural basis of lipopolysaccharide recognition by the TLR4-MD-2 complex," Nature, vol. 458, no. 7242, pp. 1191-1195, 2009.

[54] K. Miyake, "Roles for accessory molecules in microbial recognition by Toll-like receptors," Journal of Endotoxin Research, vol. 12, no. 4, pp. 195-204, 2006.

[55] D. P. Rossignol and M. Lynn, "TLR4 antagonists for endotoxemia and beyond," Current Opinion in Investigational Drugs, vol. 6, no. 5, pp. 496-502, 2005.

[56] A. Teghanemt, D. Zhang, E. N. Levis, J. P. Weiss, and T. L. Gioannini, "Molecular basis of reduced potency of underacylated endotoxins," Journal of Immunology, vol. 175, no. 7, pp. 4669-4676, 2005.

[57] R. Shimazu, S. Akashi, H. Ogata et al., "MD-2, a molecule that confers lipopolysaccharide responsiveness on Toll-like receptor 4," Journal of Experimental Medicine, vol. 189, no. 11, pp. 1777-1782, 1999.

[58] H. Hammad, M. Chieppa, F. Perros, M. A. Willart, R. N. Germain, and B. N. Lambrecht, "House dust mite allergen induces asthma via Toll-like receptor 4 triggering of airway structural cells," Nature Medicine, vol. 15, no. 4, pp. 410-416, 2009.

[59] A. Trompette, S. Divanovic, A. Visintin et al., "Allergenicity resulting from functional mimicry of a Toll-like receptor complex protein," Nature, vol. 457, no. 7229, pp. 585-588, 2009.

[60] J. H. Youn, Y. J. Oh, E. S. Kim, J. E. Choi, and J.S. Shin, "High mobility group box 1 protein binding to lipopolysaccharide facilitates transfer of lipopolysaccharide to CD14 and enhances lipopolysaccharide-mediated TNF- $\alpha$ production in human monocytes," Journal of Immunology, vol. 180, no. 7, pp. 5067-5074, 2008.

[61] Y. Nagai, T. Kobayashi, Y. Motoi et al., "The radioprotective 105/MD-1 complex links TLR2 and TLR4/MD-2 in antibody response to microbial membranes," Journal of Immunology, vol. 174, no. 11, pp. 7043-7049, 2005.

[62] S. Divanovic, A. Trompette, S. F. Atabani et al., "Negative regulation of Toll-like receptor 4 signaling by the Toll-like receptor homolog RP105," Nature Immunology, vol. 6, no. 6, pp. 571-578, 2005.

[63] E. Latz, A. Visintin, E. Lien et al., "Lipopolysaccharide rapidly traffics to and from the golgi apparatus with the Tolllike receptor $4-\mathrm{MD}-2-\mathrm{CD} 14$ complex in a process that is distinct from the initiation of signal transduction," Journal of Biological Chemistry, vol. 277, no. 49, pp. 47834-47843, 2002.

[64] Z. Jiang, P. Georgel, X. Du et al., "CD14 is required for MyD88-independent LPS signaling," Nature Immunology, vol. 6, no. 6, pp. 565-570, 2005.

[65] T. Nakata, M. Yasuda, M. Fujita et al., "CD14 directly binds to triacylated lipopeptides and facilitates recognition of the lipopeptides by the receptor complex of Toll-like receptors 2 and 1 without binding to the complex," Cellular Microbiology, vol. 8, no. 12, pp. 1899-1909, 2006.

[66] H.-K. Lee, S. Dunzendorfer, K. Soldau, and P. S. Tobias, "Double-stranded RNA-mediated TLR3 activation is enhanced by CD14," Immunity, vol. 24, no. 2, pp. 153-163, 2006.

[67] K. Hoebe, P. Georgel, S. Rutschmann, et al., "CD36 is a sensor of diacylglycerides," Nature, vol. 433, no. 7025, pp. 523-527, 2005.

[68] H. S. Park, H. Y. Jung, E. Y. Park, J. Kim, W. J. Lee, and Y. S. Bae, "Cutting edge: direct interaction of TLR4 with $\mathrm{NAD}(\mathrm{P}) \mathrm{H}$ oxidase 4 isozyme is essential for lipopolysaccharide-induced production of reactive oxygen species and activation of NF- $\kappa \mathrm{B}$," Journal of Immunology, vol. 173, no. 6, pp. 3589-3593, 2004.

[69] H. S. Park, J. N. Chun, H. Y. Jung, C. Choi, and Y. S. Bae, "Role of NADPH oxidase 4 in lipopolysaccharide-induced proinflammatory responses by human aortic endothelial cells," Cardiovascular Research, vol. 72, no. 3, pp. 447-455, 2006.

[70] B. N. Gantner, R. M. Simmons, S. J. Canavera, S. Akira, and D. M. Underhill, "Collaborative induction of inflammatory responses by dectin-1 and Toll-like receptor 2," Journal of Experimental Medicine, vol. 197, no. 9, pp. 1107-1117, 2003.

[71] D. M. E. Bowdish, K. Sakamoto, M.-J. Kim et al., "MARCO, TLR2, and CD14 are required for macrophage cytokine responses to mycobacterial trehalose dimycolate and mycobacterium tuberculosis," PLoS Pathogens, vol. 5, no. 6, Article ID e1000474, 2009.

[72] G. Horvath, S. Young, and E. Latz, "Toll-like receptor interactions imaged by FRET microscopy and GFP fragment reconstitution," Methods in Molecular Biology, vol. 517, pp. 33-54, 2009.

[73] S. Murakami, D. Iwaki, H. Mitsuzawa et al., "Surfactant protein A inhibits peptidoglycan-induced tumor necrosis factor- $\alpha$ secretion in U937 cells and alveolar macrophages by direct interaction with Toll-like receptor 2," Journal of Biological Chemistry, vol. 277, no. 9, pp. 6830-6837, 2002.

[74] M. Sato, H. Sano, D. Iwaki et al., "Direct binding of Tolllike receptor 2 to zymosan, and zymosan-induced NF- $\kappa \mathrm{B}$ activation and TNF- $\alpha$ secretion are down-regulated by lung 
collectin surfactant protein A," Journal of Immunology, vol. 171, no. 1, pp. 417-425, 2003.

[75] C. P. Hodgkinson, K. Patel, and S. Ye, "Functional Toll-like receptor 4 mutations modulate the response to fibrinogen," Thrombosis and Haemostasis, vol. 100, no. 2, pp. 301-307, 2008.

[76] Y. I. Miller, S. Viriyakosol, C. J. Binder, J. R. Feramisco, T. N. Kirkland, and J. L. Witztum, "Minimally modified LDL binds to CD14, induces macrophage spreading via TLR4/MD2, and inhibits phagocytosis of apoptotic cells," Journal of Biological Chemistry, vol. 278, no. 3, pp. 1561-1568, 2003.

[77] A. Kol, A. H. Lichtman, R. W. Finberg, P. Libby, and E. A. Kurt-Jones, "Cutting edge: heat shock protein (HSP) 60 activates the innate immune response: CD14 is an essential receptor for HSP60 activation of mononuclear cells," Journal of Immunology, vol. 164, no. 1, pp. 13-17, 2000.

[78] L. Guillot, V. Balloy, F. X. McCormack, D. T. Golenbock, M. Chignard, and M. Si-Tahar, "Cutting edge: the immunostimulatory activity of the lung surfactant protein-A involves Tolllike receptor 4," Journal of Immunology, vol. 168, no. 12, pp. 5989-5992, 2002.

[79] M. Ohya, C. Nishitani, H. Sano et al., "Human pulmonary surfactant protein D binds the extracellular domains of Tolllike receptors 2 and 4 through the carbohydrate recognition domain by a mechanism different from its binding to phosphatidylinositol and lipopolysaccharide," Biochemistry, vol. 45, no. 28, pp. 8657-8664, 2006.

[80] C. S. Curran, K. P. Demick, and J. M. Mansfield, "Lactoferrin activates macrophages via TLR4-dependent andindependent signaling pathways," Cellular Immunology, vol. 242, no. 1, pp. 23-30, 2006.

[81] Y. Okamura, M. Watari, E. S. Jerud et al., "The extra domain a of fibronectin activates Toll-like receptor 4," Journal of Biological Chemistry, vol. 276, no. 13, pp. 10229-10233, 2001.

[82] H. Shi, M. V. Kokoeva, K. Inouye, I. Tzameli, H. Yin, and J. S. Flier, "TLR4 links innate immunity and fatty acid-induced insulin resistance," Journal of Clinical Investigation, vol. 116, no. 11, pp. 3015-3025, 2006.

[83] R. de Graaf, G. Kloppenburg, P. J. H. M. Kitslaar, C. A. Bruggeman, and F. Stassen, "Human heat shock protein 60 stimulates vascular smooth muscle cell proliferation through Toll-like receptors 2 and 4," Microbes and Infection, vol. 8, no. 7, pp. 1859-1865, 2006.

[84] J.-M. Koh, Y.-S. Lee, Y. S. Kim et al., "Heat shock protein 60 causes osteoclastic bone resorption via Toll-like receptor-2 in estrogen deficiency," Bone, vol. 45, no. 4, pp. 650-660, 2009.

[85] M. Cohen-Sfady, G. Nussbaum, M. Pevsner-Fischer et al., "Heat shock protein 60 activates B cells via the TLR4-MyD88 pathway," Journal of Immunology, vol. 175, no. 6, pp. 35943602, 2005.

[86] S. P. Gondokaryono, H. Ushio, F. Niyonsaba et al., "The extra domain A of fibronectin stimulates murine mast cells via Toll-like receptor 4," Journal of Leukocyte Biology, vol. 82, no. 3, pp. 657-665, 2007.

[87] A. Babelova, K. Moreth, W. Tsalastra-Greul et al., "Biglycan, a danger signal that activates the NLRP3 inflammasome via Toll-like and P2X receptors," Journal of Biological Chemistry, vol. 284, no. 36, pp. 24035-24048, 2009.

[88] K. R. Taylor, K. Yamasaki, K. A. Radek et al., "Recognition of hyaluronan released in sterile injury involves a unique receptor complex dependent on Toll-like receptor 4, CD44, and MD-2," Journal of Biological Chemistry, vol. 282, no. 25, pp. 18265-18275, 2007.
[89] T. K. Means, E. Latz, F. Hayashi, M. R. Murali, D. T. Golenbock, and A. D. Luster, "Human lupus autoantibodyDNA complexes activate DCs through cooperation of CD32 and TLR9," Journal of Clinical Investigation, vol. 115, no. 2, pp. 407-417, 2005.

[90] V. Urbonaviciute, B. G. Fürnrohr, S. Meister et al., "Induction of inflammatory and immune responses by HMGB1nucleosome complexes: implications for the pathogenesis of SLE," Journal of Experimental Medicine, vol. 205, no. 13, pp. 3007-3018, 2008.

[91] R. Lande, J. Gregorio, V. Facchinetti et al., "Plasmacytoid dendritic cells sense self-DNA coupled with antimicrobial peptide," Nature, vol. 449, no. 7162, pp. 564-569, 2007.

[92] D. Ganguly, G. Chamilos, R. Lande et al., "Self-RNAantimicrobial peptide complexes activate human dendritic cells through TLR7 and TLR8," Journal of Experimental Medicine, vol. 206, no. 9, pp. 1983-1994, 2009.

[93] C. M. Lau, C. Broughton, A. S. Tabor et al., "RNAassociated autoantigens activate B cells by combined B cell antigen receptor/Toll-like receptor 7 engagement," Journal of Experimental Medicine, vol. 202, no. 9, pp. 1171-1177, 2005.

[94] G. A. Viglianti, C. M. Lau, T. M. Hanley, B. A. Miko, M. J. Shlomchik, and A. Marshak-Rothstein, "Activation of autoreactive B cells by CpG dsDNA," Immunity, vol. 19, no. 6, pp. 837-847, 2003.

[95] N. J. Gay and M. Gangloff, "Structure and function of Toll receptors and their ligands," Annual Review of Biochemistry, vol. 76, pp. 141-165, 2007.

[96] K. Mollen, K. Mollen, D. Kaczorowski, et al., "MD2 and CD14 mediate toll-like receptor 4 (TLR4) activation by high mobility group box 1 (HMGB1)," Journal of the American College of Surgeons, vol. 205, no. 3, supplement, p. S28, 2007.

[97] M. S. Jin and J.-O. Lee, "Structures of the Toll-like receptor family and its ligand complexes," Immunity, vol. 29, no. 2, pp. 182-191, 2008.

[98] E. F. Kenny and L. A. J. O’Neill, “Signalling adaptors used by Toll-like receptors: an update," Cytokine, vol. 43, no. 3, pp. 342-349, 2008.

[99] M. Hirschfeld, J. J. Weis, V. Toshchakov et al., "Signaling by Toll-like receptor 2 and 4 agonists results in differential gene expression in murine macrophages," Infection and Immunity, vol. 69, no. 3, pp. 1477-1482, 2001.

[100] B. W. Jones, K. A. Heldwein, T. K. Means, J. J. Saukkonen, and M. J. Fenton, "Differential roles of Toll-like receptors in the elicitation of proinflammatory responses by macrophages," Annals of the Rheumatic Diseases, vol. 60, supplement 3, pp. iii6-iii12, 2001.

[101] S. Agrawal, A. Agrawal, B. Doughty et al., "Cutting edge: different Toll-Like receptor agonists instruct ddendritic cells to induce distinct Th responses via differential modulation of extracellular signal-regulated kinase-mitogen-activated protein kinase and c-Fos," Journal of Immunology, vol. 171, no. 10, pp. 4984-4989, 2003.

[102] T. A. Barr, S. Brown, G. Ryan, J. Zhao, and D. Gray, “TLRmediated stimulation of APC: distinct cytokine responses of B cells and dendritic cells," European Journal of Immunology, vol. 37, no. 11, pp. 3040-3053, 2007.

[103] A. M. Lundberg, S. K. Drexler, C. Monaco et al., "Key differences in TLR3/poly I:C signaling and cytokine induction by human primary cells: a phenomenon absent from murine cell systems," Blood, vol. 110, no. 9, pp. 3245-3252, 2007. 
[104] J. S. Park, J. Arcaroli, H.-K. Yum et al., "Activation of gene expression in human neutrophils by high mobility group box 1 protein," American Journal of Physiology, vol. 284, no. 4, pp. C870-C879, 2003.

[105] E. Silva, J. Arcaroli, Q. He et al., "HMGB1 and LPS induce distinct patterns of gene expression and activation in neutrophils from patients with sepsis-induced acute lung injury," Intensive Care Medicine, vol. 33, no. 10, pp. 18291839, 2007.

[106] H. F. Dvorak, D. R. Senger, and A. M. Dvorak, "Regulation of extravascular coagulation by microvascular permeability," Science, vol. 227, no. 4690, pp. 1059-1061, 1985.

[107] S. S. McCachren and V. A. Lightner, "Expression of human tenascin in synovitis and its regulation by interleukin-1," Arthritis and Rheumatism, vol. 35, no. 10, pp. 1185-1196, 1992.

[108] D. M. Salter, "Tenascin is increased in cartilage and synovium from arthritic knees," British Journal of Rheumatology, vol. 32, no. 9, pp. 780-786, 1993.

[109] G. Schett, K. Redlich, Q. Xu et al., "Enhanced expression of heat shock protein 70 (hsp70) and heat shock factor 1 (HSF1) activation in rheumatoid arthritis synovial tissue: differential regulation of hsp70 expression and hsf1 activation in synovial fibroblasts by proinflammatory cytokines, shear stress, and antiinflammatory drugs," Journal of Clinical Investigation, vol. 102, no. 2, pp. 302-311, 1998.

[110] D. L. Scott, J. P. Delamere, and K. W. Walton, "The distribution of fibronectin in the pannus in rheumatoid arthritis," British Journal of Experimental Pathology, vol. 62, no. 4, pp. 362-368, 1981.

[111] N. Taniguchi, K.-I. Kawahara, K. Yone et al., "High mobility group box chromosomal protein 1 plays a role in the pathogenesis of rheumatoid arthritis as a novel cytokine," Arthritis and Rheumatism, vol. 48, no. 4, pp. 971-981, 2003.

[112] D. Yu, P. M. Rumore, Q. Liu, and C. R. Steinman, "Soluble oligonucleosomal complexes in synovial fluid from inflamed joints," Arthritis and Rheumatism, vol. 40, no. 4, pp. 648-654, 1997.

[113] S. Schenk, J. Muser, G. Vollmer, and R. Chiquet-Ehrismann, "Tenascin-C in serum: a questionable tumor marker," International Journal of Cancer, vol. 61, no. 4, pp. 443-449, 1995.

[114] H. Wang, O. Bloom, M. Zhang et al., "HMG-1 as a late mediator of endotoxin lethality in mice," Science, vol. 285, no. 5425, pp. 248-251, 1999.

[115] V. Urbonaviciute, B. G. Fürnrohr, C. Weber et al., "Factors masking HMGB1 in human serum and plasma," Journal of Leukocyte Biology, vol. 81, no. 1, pp. 67-74, 2007.

[116] R. Hallgren, A. Eklund, A. Engstrom-Laurent, and B. Schmekel, "Hyaluronate in bronchoalveolar lavage fluid: a new marker in sarcoidosis reflecting pulmonary disease," British Medical Journal, vol. 290, no. 6484, pp. 1778-1781, 1985.

[117] N. Milman, M. S. Kristensen, and K. Bentsen, "Hyaluronan and procollagen type III aminoterminal peptide in serum and bronchoalveolar lavage fluid from patients with pulmonary fibrosis," APMIS, vol. 103, no. 10, pp. 749-754, 1995.

[118] G. C. Riise, S. Ahlstedt, S. Larsson et al., "Bronchial inflammation in chronic bronchitis assessed by measurement of cell products in bronchial lavage fluid," Thorax, vol. 50, no. 4, pp. 360-365, 1995.

[119] A. Andersson, R. Covacu, D. Sunnemark et al., "Pivotal advance: HMGB1 expression in active lesions of human and experimental multiple sclerosis," Journal of Leukocyte Biology, vol. 84, no. 5, pp. 1248-1255, 2008.
[120] D. Foell, H. Wittkowski, T. Vogl, and J. Roth, "S100 proteins expressed in phagocytes: a novel group of damage-associated molecular pattern molecules," Journal of Leukocyte Biology, vol. 81, no. 1, pp. 28-37, 2007.

[121] G. B. Johnson, G. J. Brunn, and J. L. Platt, "Cutting edge: an endogenous pathway to systemic inflammatory response syndrome (SIRS)-like reactions through Toll-Like receptor 4," Journal of Immunology, vol. 172, no. 1, pp. 20-24, 2004.

[122] J. J. Maher, "DAMPs ramp up drug toxicity," Journal of Clinical Investigation, vol. 119, no. 2, pp. 246-249, 2009.

[123] K. J. Ishii, K. Suzuki, C. Coban et al., "Genomic DNA released by dying cells induces the maturation of APCs," Journal of Immunology, vol. 167, no. 5, pp. 2602-2607, 2001.

[124] S.-A. Hwang, M. L. Kruzel, and J. K. Actor, "Lactoferrin augments BCG vaccine efficacy to generate $\mathrm{T}$ helper response and subsequent protection against challenge with virulent Mycobacterium tuberculosis," International Immunopharmacology, vol. 5, no. 3, pp. 591-599, 2005.

[125] K. A. Scheibner, M. A. Lutz, S. Boodoo, M. J. Fenton, J. D. Powell, and M. R. Horton, "Hyaluronan fragments act as an endogenous danger signal by engaging TLR2," Journal of Immunology, vol. 177, no. 2, pp. 1272-1281, 2006.

[126] K. Tani, W. J. Murphy, O. Chertov et al., "Defensins act as potent adjuvants that promote cellular and humoral immune responses in mice to a lymphoma idiotype and carrier antigens," International Immunology, vol. 12, no. 5, pp. 691700, 2000.

[127] P. Rovere-Querini, A. Capobianco, P. Scaffidi et al., "HMGB1 is an endogenous immune adjuvant released by necrotic cells," EMBO Reports, vol. 5, no. 8, pp. 825-830, 2004.

[128] A. Kawakami, M. Osaka, M. Aikawa et al., "Toll-like receptor 2 mediates apolipoprotein CIII-induced monocyte activation," Circulation Research, vol. 103, no. 12, pp. 1402-1409, 2008.

[129] D. Agnello, H. Wang, H. Yang, K. J. Tracey, and P. Ghezzi, "HMGB-1, a DNA-binding protein with cytokine activity, induces brain TNF and IL-6 production, and mediates anorexia and taste aversion," Cytokine, vol. 18, no. 4, pp. 231236, 2002.

[130] K. Liu, S. Mori, H. K. Takahashi et al., "Anti-high mobility group box 1 monoclonal antibody ameliorates brain infarction induced by transient ischemia in rats," FASEB Journal, vol. 21, no. 14, pp. 3904-3916, 2007.

[131] K. A. O'Connor, M. K. Hansen, C. R. Pugh et al., "Further characterization of high mobility group box 1 (HMGB1) as a proinflammatory cytokine: central nervous system effects," Cytokine, vol. 24, no. 6, pp. 254-265, 2003.

[132] P. L. Sappington, R. Yang, H. Yang, K. J. Tracey, R. L. Delude, and M. P. Fink, "HMGB1 B box increases the permeability of Caco-2 enterocytic monolayers and impairs intestinal barrier function in mice," Gastroenterology, vol. 123, no. 3, pp. 790802, 2002.

[133] R. Pullerits, I.-M. Jonsson, M. Verdrengh et al., "High mobility group box chromosomal protein 1, a DNA binding cytokine, induces arthritis," Arthritis and Rheumatism, vol. 48, no. 6, pp. 1693-1700, 2003.

[134] A. B. Imaeda, A. Watanabe, M. A. Sohail et al., "Acetaminophen-induced hepatotoxicity in mice is dependent on Tlr9 and the Nalp3 inflammasome," Journal of Clinical Investigation, vol. 119, no. 2, pp. 305-314, 2009.

[135] A. Tsung, R. Sahai, H. Tanaka et al., "The nuclear factor HMGB1 mediates hepatic injury after murine liver ischemiareperfusion," Journal of Experimental Medicine, vol. 201, no. 7, pp. 1135-1143, 2005. 
[136] E. Abraham, J. Arcaroli, A. Carmody, H. Wang, and K. J. Tracey, "Cutting edge: HMG-1 as a mediator of acute lung inflammation," Journal of Immunology, vol. 165, no. 6, pp. 2950-2954, 2000.

[137] X. Lin, H. Yang, T. Sakuragi, et al., " $\alpha$-chemokine receptor blockade reduces high mobility group box 1 protein-induced lung inflammation and injury and improves survival in sepsis," American Journal of Physiology, vol. 289, no. 4, pp. L583-L590, 2005.

[138] H. Ueno, T. Matsuda, S. Hashimoto et al., "Contributions of high mobility group box protein in experimental and clinical acute lung injury," American Journal of Respiratory and Critical Care Medicine, vol. 170, no. 12, pp. 1310-1316, 2004.

[139] M. H. Tan, Z. Sun, S. L. Opitz, T. E. Schmidt, J. H. Peters, and E. L. George, "Deletion of the alternatively spliced fibronectin EIIIA domain in mice reduces atherosclerosis," Blood, vol. 104, no. 1, pp. 11-18, 2004.

[140] M. A. D. van Zoelen, T. Vogl, D. Foell, et al., "Expression and role of myeloid-related protein-14 in clinical and experimental sepsis," American Journal of Respiratory and Critical Care Medicine, vol. 180, no. 11, pp. 1098-1106, 2009.

[141] K. Croce, H. Gao, Y. Wang et al., "Myeloid-related protein$8 / 14$ is critical for the biological response to vascular injury," Circulation, vol. 120, no. 5, pp. 427-436, 2009.

[142] G. Ziegler, V. Prinz, M. W. Albrecht et al., "Mrp-8 and -14 mediate CNS injury in focal cerebral ischemia," Biochimica et Biophysica Acta, vol. 1792, no. 12, pp. 1198-1204, 2009.

[143] T. Vogl, K. Tenbrock, S. Ludwig et al., "Mrp8 and Mrp14 are endogenous activators of Toll-like receptor 4, promoting lethal, endotoxin-induced shock," Nature Medicine, vol. 13, no. 9, pp. 1042-1049, 2007.

[144] J. F. Talts, G. Wirl, M. Dictor, W. J. Muller, and R. Fässler, "Tenascin-C modulates tumor stroma and monocyte/macrophage recruitment but not tumor growth or metastasis in a mouse strain with spontaneous mammary cancer," Journal of Cell Science, vol. 112, no. 12, pp. 18551864, 1999.

[145] D. Jiang, J. Liang, J. Fan et al., "Regulation of lung injury and repair by Toll-like receptors and hyaluronan," Nature Medicine, vol. 11, no. 11, pp. 1173-1179, 2005.

[146] Y.-Y. Liu, C.-H. Lee, R. Dedaj et al., "High-molecular-weight hyaluronan-a possible new treatment for sepsis-induced lung injury: a preclinical study in mechanically ventilated rats," Critical Care, vol. 12, no. 4, article R102, 2008.

[147] S. H. Davé, J. S. Tilstra, K. Matsuoka et al., "Ethyl pyruvate decreases HMGB1 release and ameliorates murine colitis," Journal of Leukocyte Biology, vol. 86, no. 3, pp. 633-643, 2009.

[148] S. Maeda, Y. Hikiba, W. Shibata et al., "Essential roles of highmobility group box 1 in the development of murine colitis and colitis-associated cancer," Biochemical and Biophysical Research Communications, vol. 360, no. 2, pp. 394-400, 2007.

[149] E. N. Ogawa, A. Ishizaka, S. Tasaka et al., "Contribution of high-mobility group box-1 to the development of ventilatorinduced lung injury," American Journal of Respiratory and Critical Care Medicine, vol. 174, no. 4, pp. 400-407, 2006.

[150] H. Sawa, T. Ueda, Y. Takeyama et al., "Blockade of high mobility group box-1 protein attenuates experimental severe acute pancreatitis," World Journal of Gastroenterology, vol. 12, no. 47, pp. 7666-7670, 2006.

[151] R. Yang, T. Harada, K. P. Mollen et al., "Anti-HMGB1 neutralizing antibody ameliorates gut barrier dysfunction and improves survival after hemorrhagic shock," Molecular Medicine, vol. 12, no. 4-6, pp. 105-114, 2006.
[152] J. Y. Kim, J. S. Park, D. Strassheim et al., "HMGB1 contributes to the development of acute lung injury after hemorrhage," American Journal of Physiology, vol. 288, no. 5, pp. L958L965, 2005.

[153] K. Suda, Y. Kitagawa, S. Ozawa et al., "Anti-high-mobility group box chromosomal protein 1 antibodies improve survival of rats with sepsis," World Journal of Surgery, vol. 30, no. 9, pp. 1755-1762, 2006.

[154] H. Yang, M. Ochani, J. Li et al., "Reversing established sepsis with antagonists of endogenous high-mobility group box 1," Proceedings of the National Academy of Sciences of the United States of America, vol. 101, no. 1, pp. 296-301, 2004.

[155] S. Qin, H. Wang, R. Yuan et al., "Role of HMGB1 in apoptosis-mediated sepsis lethality," Journal of Experimental Medicine, vol. 203, no. 7, pp. 1637-1642, 2006.

[156] G. Chen, J. Li, X. Qiang et al., "Suppression of HMGB1 release by stearoyl lysophosphatidylcholine: an additional mechanism for its therapeutic effects in experimental sepsis," Journal of Lipid Research, vol. 46, no. 4, pp. 623-627, 2005.

[157] L. Ulloa, F. M. Batliwalla, U. Andersson, P. K. Gregersen, and K. J. Tracey, "High mobility group box chromosomal protein 1 as a nuclear protein, cytokine, and potential therapeutic target in arthritis," Arthritis and Rheumatism, vol. 48, no. 4, pp. 876-881, 2003.

[158] H. Wang, H. Liao, M. Ochani et al., "Cholinergic agonists inhibit HMGB1 release and improve survival in experimental sepsis," Nature Medicine, vol. 10, no. 11, pp. 1216-1221, 2004.

[159] A. Chorny and M. Delgado, "Neuropeptides rescue mice from lethal sepsis by down-regulating secretion of the lateacting inflammatory mediator high mobility group box 1," American Journal of Pathology, vol. 172, no. 5, pp. 1297-1302, 2008.

[160] P. Pan, J. Cardinal, R. Dhupar et al., "Low-dose cisplatin administration in murine cecal ligation and puncture prevents the systemic release of HMGB1 and attenuates lethality," Journal of Leukocyte Biology, vol. 86, no. 3, pp. 625-632, 2009.

[161] U. Andersson and H. Erlandsson-Harris, "HMGB1 is a potent trigger of arthritis," Journal of Internal Medicine, vol. 255, no. 3, pp. 344-350, 2004.

[162] J. W. Rice, J. M. Veal, R. P. Fadden et al., "Small molecule inhibitors of Hsp90 potently affect inflammatory disease pathways and exhibit activity in models of rheumatoid arthritis," Arthritis and Rheumatism, vol. 58, no. 12, pp. 37653775, 2008.

[163] R. I. Feldman, B. Mintzer, D. Zhu et al., "Potent triazolothione inhibitor of heat-shock protein-90," Chemical Biology and Drug Design, vol. 74, no. 1, pp. 43-50, 2009.

[164] S. Hagiwara, H. Iwasaka, K. Togo, and T. Noguchi, "A neutrophil elastase inhibitor, sivelestat, reduces lung injury following endotoxin-induced shock in rats by inhibiting HMGB1," Inflammation, vol. 31, no. 4, pp. 227-234, 2008.

[165] N. Harada, K. Okajima, and H. Isobe, "Role of neutrophil elastase in development of pulmonary vascular injury and septic shock in rats," Shock, vol. 30, no. 4, pp. 379-387, 2008.

[166] Y. Morohoshi, K. Matsuoka, H. Chinen et al., "Inhibition of neutrophil elastase prevents the development of murine dextran sulfate sodium-induced colitis," Journal of Gastroenterology, vol. 41, no. 4, pp. 318-324, 2006.

[167] K. Kakimoto, A. Matsukawa, M. Yoshinaga, and H. Nakamura, "Suppressive effect of a neutrophil elastase inhibitor on the development of collagen-induced arthritis," Cellular Immunology, vol. 165, no. 1, pp. 26-32, 1995. 
[168] Y. Uchida, M. C. S. Freitas, D. Zhao, R. W. Busuttil, and J. W. Kupiec-Weglinski, "The inhibition of neutrophil elastase ameliorates mouse liver damage due to ischemia and reperfusion," Liver Transplantation, vol. 15, no. 8, pp. 939$947,2009$.

[169] S. Hiratsuka, A. Watanabe, Y. Sakurai et al., "The S100A8serum amyloid A3-TLR4 paracrine cascade establishes a premetastatic phase," Nature Cell Biology, vol. 10, no. 11, pp. 1349-1355, 2008.

[170] M. T. Lotze and K. J. Tracey, "High-mobility group box 1 protein (HMGB1): nuclear weapon in the immune arsenal," Nature Reviews Immunology, vol. 5, no. 4, pp. 331-342, 2005.

[171] L. L. Mantell, W. R. Parrish, and L. Ulloa, "Hmgb-1 as a therapeutic target for infectious and inflammatory disorders," Shock, vol. 25, no. 1, pp. 4-11, 2006.

[172] W. R. Parrish, M. Gallowitsch-Puerta, C. J. Czura, and K. J. Tracey, "Experimental therapeutic strategies for severe sepsis: mediators and mechanisms," Annals of the New York Academy of Sciences, vol. 1144, pp. 210-236, 2008.

[173] R. E. Voll, V. Urbonaviciute, B. Fürnrohr, M. Herrmann, and J. R. Kalden, "The role of high-mobility group box 1 protein in the pathogenesis of autoimmune diseases," Current Rheumatology Reports, vol. 10, no. 5, pp. 341-342, 2008.

[174] H. Wang, H. Yang, and K. J. Tracey, "Extracellular role of HMGB1 in inflammation and sepsis," Journal of Internal Medicine, vol. 255, no. 3, pp. 320-331, 2004.

[175] D. S. Pisetsky, H. Erlandsson-Harris, and U. Andersson, "High-mobility group box protein 1 (HMGB1): an alarmin mediating the pathogenesis of rheumatic disease," Arthritis Research and Therapy, vol. 10, no. 3, p. 209, 2008.

[176] D. Musumeci, G. N. Roviello, M. Moccia et al., "Bent oligonucleotide duplexes as HMGB1 inhibitors: a comparative study," Nucleosides, Nucleotides and Nucleic Acids, vol. 26, no. 10-12, pp. 1447-1450, 2007.

[177] Z. Yuan, J. Chen, Y. Zhang, and Y. Peng, "Construction and characterization of the HMGB1 mutant as a competitive antagonist to HMGB1 induced cytokines release," Biochemical and Biophysical Research Communications, vol. 372, no. 4, pp. 703-707, 2008.

[178] K. Abeyama, D. M. Stern, Y. Ito et al., "The Nterminal domain of thrombomodulin sequesters highmobility group-B1 protein, a novel antiinflammatory mechanism," Journal of Clinical Investigation, vol. 115, no. 5, pp. 1267-1274, 2005.

[179] P. Scaffidi, T. Misteli, and M. E. Bianchi, "Release of chromatin protein HMGB1 by necrotic cells triggers inflammation," Nature, vol. 418, no. 6894, pp. 191-195, 2002.

[180] S. Gardella, C. Andrei, D. Ferrera et al., "The nuclear protein HMGB1 is secreted by monocytes via a non-classical, vesiclemediated secretory pathway," EMBO Reports, vol. 3, no. 10, pp. 995-1001, 2002.

[181] D. Foell, H. Wittkowski, and J. Roth, "Mechanisms of disease: a 'DAMP' view of inflammatory arthritis," Nature Clinical Practice Rheumatology, vol. 3, no. 7, pp. 382-390, 2007.

[182] G. J. Brunn, M. K. Bungum, G. B. Johnson, and J. L. Platt, "Conditional signaling by Toll-like receptor 4," FASEB Journal, vol. 19, no. 7, pp. 872-874, 2005.

[183] C. R. Kliment, J. M. Tobolewski, M. L. Manni, R. J. Tan, J. Enghild, and T. D. Oury, "Extracellular superoxide dismutase protects against matrix degradation of heparan sulfate in the lung," Antioxidants and Redox Signaling, vol. 10, no. 2, pp. 261-268, 2008.
[184] M. Goto, T. Hanyu, T. Yoshio et al., "Intra-articular injection of hyaluronate (SI-6601D) improves joint pain and synovial fluid prostaglandin E2 levels in rheumatoid arthritis: a multicenter clinical trial," Clinical and Experimental Rheumatology, vol. 19, no. 4, pp. 377-383, 2001.

[185] W. Van Eden, R. Van Der Zee, and B. Prakken, "Heat-shock proteins induce T-cell regulation of chronic inflammation," Nature Reviews Immunology, vol. 5, no. 4, pp. 318-330, 2005.

[186] M. Hayakawa, K. Katabami, T. Wada, et al., "Sivelestat (selective neutrophil elastase inhibitor) improves the mortality rate of sepsis associated with both acute respiratory distress syndrome and disseminated intravascular coagulation patients," Shock, vol. 33, no. 1, pp. 14-18, 2010.

[187] S. Togo, K. Matsuo, A. Ishibe et al., "Usefulness of a selective neutrophil elastase inhibitor (sivelestat) in septic ARDS patients after gastrointestinal surgery," HepatoGastroenterology, vol. 55, no. 84, pp. 967-973, 2008.

[188] K. Izuishi, A. Tsung, G. Jeyabalan et al., "Cutting edge: highmobility group box 1 preconditioning protects against liver ischemia-reperfusion injury," Journal of Immunology, vol. 176, no. 12, pp. 7154-7158, 2006.

[189] J. R. Klune, T. R. Billiar, and A. Tsung, "HMGB1 preconditioning: therapeutic application for a danger signal?" Journal of Leukocyte Biology, vol. 83, no. 3, pp. 558-563, 2008.

[190] T. Zagulski, P. Lipinski, A. Zagulska, S. Broniek, and Z. Jarzabek, "Lactoferrin can protect mice against a lethal dose of Escherichia coli in experimental infection in vivo," British Journal of Experimental Pathology, vol. 70, no. 6, pp. 697-704, 1989.

[191] S. Gariboldi, M. Palazzo, L. Zanobbio et al., "Low molecular weight hyaluronic acid increases the self-defense of skin epithelium by induction of $\beta$-defensin 2 via TLR 2 and TLR4," Journal of Immunology, vol. 181, no. 3, pp. 2103-2110, 2008.

[192] E. J. Chesler, D. R. Miller, L. R. Branstetter et al., "The Collaborative Cross at Oak Ridge National Laboratory: developing a powerful resource for systems genetics," Mammalian Genome, vol. 19, no. 6, pp. 382-389, 2008.

[193] L. A. J. O’Neill, “When signaling pathways collide: positive and negative regulation of Toll-like receptor signal transduction," Immunity, vol. 29, no. 1, pp. 12-20, 2008.

[194] J. Stack, I. R. Haga, M. Schröder et al., "Vaccinia virus protein A46R targets multiple Toll-like-interleukin-1 receptor adaptors and contributes to virulence," Journal of Experimental Medicine, vol. 201, no. 6, pp. 1007-1018, 2005.

[195] K. Li, E. Foy, J. C. Ferreon et al., "Immune evasion by hepatitis $\mathrm{C}$ virus NS3/4A protease-mediated cleavage of the Toll-like receptor 3 adaptor protein TRIF," Proceedings of the National Academy of Sciences of the United States of America, vol. 102, no. 8, pp. 2992-2997, 2005.

[196] G. Liu, A. Friggeri, Y. Yang, Y.-J. Park, Y. Tsuruta, and E. Abraham, "miR-147, a microRNA that is induced upon Toll-like receptor stimulation, regulates murine macrophage inflammatory responses," Proceedings of the National Academy of Sciences of the United States of America, vol. 106, no. 37, pp. 15819-15824, 2009.

[197] Y. Liu, G.-Y. Chen, and P. Zheng, "CD24-Siglec G/10 discriminates danger- from pathogen-associated molecular patterns," Trends in Immunology, vol. 30, no. 12, pp. 557-561, 2009.

[198] G.-Y. Chen, J. Tang, P. Zheng, and Y. Liu, "CD24 and siglec-10 selectively repress tissue damage-induced immune responses," Science, vol. 323, no. 5922, pp. 1722-1725, 2009. 
[199] A. C. Raby, E. Le Bouder, C. Colmont et al., "Soluble TLR2 reduces inflammation without compromising bacterial clearance by disrupting TLR2 triggering," Journal of Immunology, vol. 183, no. 1, pp. 506-517, 2009.

[200] S. T. Smiley, J. A. King, and W. W. Hancock, "Fibrinogen stimulates macrophage chemokine secretion through Tolllike receptor 4," Journal of Immunology, vol. 167, no. 5, pp. 2887-2894, 2001.

[201] R. L. He, J. Zhou, C. Z. Hanson, J. Chen, N. Cheng, and R. D. Ye, "Serum amyloid A induces G-CSF expression and neutrophilia via Toll-like receptor 2," Blood, vol. 113, no. 2, pp. 429-437, 2009.

[202] S. Sandri, D. Rodriguez, E. Gomes, H. P. Monteiro, M. Russo, and A. Campa, "Is serum amyloid A an endogenous TLR4 agonist?" Journal of Leukocyte Biology, vol. 83, no. 5, pp. 1174-1180, 2008.

[203] N. Cheng, R. He, J. Tian, P. P. Ye, and R. D. Ye, "Cutting edge: TLR2 is a functional receptor for acute-phase serum amyloid A," Journal of Immunology, vol. 181, no. 1, pp. 22-26, 2008.

[204] A. Biragyn, P. A. Ruffini, C. A. Leifer et al., "Toll-like receptor 4-dependent activation of dendritic cells by $\beta$-defensin 2," Science, vol. 298, no. 5595, pp. 1025-1029, 2002.

[205] J. M. Devaney, C. M. Greene, C. C. Taggart, T. P. Carroll, S. J. O’Neill, and N. G. McElvaney, "Neutrophil elastase upregulates interleukin-8 via Toll-like receptor 4," FEBS Letters, vol. 544, no. 1-3, pp. 129-132, 2003.

[206] X. H. Xu, P. K. Shah, E. Faure et al., "Toll-like receptor-4 is expressed by macrophages in murine and human lipid-rich atherosclerotic plaques and upregulated by oxidized LDL," Circulation, vol. 104, no. 25, pp. 3103-3108, 2001.

[207] Y. S. Bae, J. H. Lee, S. H. Choi et al., "Macrophages generate reactive oxygen species in response to minimally oxidized low-density lipoprotein: Toll-like receptor 4- and spleen tyrosine kinase-dependent activation of NADPH oxidase 2," Circulation Research, vol. 104, no. 2, pp. 210-218, 2009.

[208] A. Schaeffler, P. Gross, R. Buettner et al., "Fatty acidinduced induction of Toll-like receptor-4/nuclear factor- $\kappa \mathrm{B}$ pathway in adipocytes links nutritional signalling with innate immunity," Immunology, vol. 126, no. 2, pp. 233-245, 2009.

[209] D. Yang, Q. Chen, B. S. Shao et al., "Eosinophil-derived neurotoxin acts as an alarmin to activate the TLR2-MyD88 signal pathway in dendritic cells and enhances Th2 immune responses," Journal of Experimental Medicine, vol. 205, no. 1, pp. 79-90, 2008.

[210] P. J. Little, N. Osman, and K. D. O’Brien, "Hyperelongated biglycan: the surreptitious initiator of atherosclerosis," Current Opinion in Lipidology, vol. 19, no. 5, pp. 448-454, 2008.

[211] K. J. Williams, "Arterial wall chondroitin sulfate proteoglycans: diverse molecules with distinct roles in lipoprotein retention and atherogenesis," Current Opinion in Lipidology, vol. 12, no. 5, pp. 477-487, 2001.

[212] L. Schaefer, I. Raslik, H. J. Grone, et al., "Small proteoglycans in human diabetic nephropathy: discrepancy between glomerular expression and protein accumulation of decorin, biglycan, lumican, and fibromodulin," FASEB Journal, vol. 15, no. 3, pp. 559-561, 2001.

[213] G. Cs-Szabo, P. J. Roughley, A. H. K. Plaas, and T. T. Glant, "Large and small proteoglycans of osteoarthritic and rheumatoid articular cartilage," Arthritis and Rheumatism, vol. 38, no. 5, pp. 660-668, 1995.

[214] A. Polgár, A. Falus, É. Koó, et al., "Elevated levels of synovial fluid antibodies reactive with the small proteoglycans biglycan and decorin in patients with rheumatoid arthritis or other joint diseases," Rheumatology, vol. 42, no. 4, pp. 522527, 2003.

[215] O. Galamb, F. Sipos, S. Spisák et al., "Potential biomarkers of colorectal adenoma-dysplasia-carcinoma progression: mRNA expression profiling and in situ protein detection on TMAs reveal 15 sequentially upregulated and 2 downregulated genes," Cellular Oncology, vol. 31, no. 1, pp. 19-29, 2009.

[216] R. Nishino, M. Honda, T. Yamashita et al., "Identification of novel candidate tumour marker genes for intrahepatic cholangiocarcinoma," Journal of Hepatology, vol. 49, no. 2, pp. 207-216, 2008.

[217] M. B. Mintz, R. Sowers, K. M. Brown et al., "An expression signature classifies chemotherapy-resistant pediatric osteosarcoma," Cancer Research, vol. 65, no. 5, pp. 17481754, 2005.

[218] C. K. Weber, G. Sommer, P. Michl et al., "Biglycan is overexpressed in pancreatic cancer and induces G1-arrest in pancreatic cancer cell lines," Gastroenterology, vol. 121, no. 3, pp. 657-667, 2001.

[219] J. Danesh, S. Lewington, S. G. Thompson et al., "Plasma fibrinogen level and the risk of major cardiovascular diseases and nonvascular mortality: an individual participant metaanalysis," Journal of the American Medical Association, vol. 294, no. 14, pp. 1799-1809, 2005.

[220] G. Di Minno and M. Mancini, "Measuring plasma fibrinogen to predict stroke and myocardial infarction," Arteriosclerosis, vol. 10, no. 1, pp. 1-7, 1990.

[221] R. A. Adams, C. Schachtrup, D. Davalos, I. Tsigelny, and K. Akassoglou, "Fibrinogen signal transduction as a mediator and therapeutic target in inflammation: lessons from multiple sclerosis," Current Medicinal Chemistry, vol. 14, no. 27, pp. 2925-2936, 2007.

[222] B. J. Rybarczyk and P. J. Simpson-Haidaris, "Fibrinogen assembly, secretion, and deposition into extracellular matrix by MCF-7 human breast carcinoma cells," Cancer Research, vol. 60, no. 7, pp. 2033-2039, 2000.

[223] J. Bidwell, R. McCabe, B. Rougraff et al., "Tissue matrix protein expression in human osteoblasts, osteosarcoma tumors, and osteosarcoma cell lines," Molecular Biology Reports, vol. 24, no. 4, pp. 271-282, 1997.

[224] J. K. van Keulen, D. P. de Kleijn, M. M. O. Nijhuis et al., "Levels of extra domain A containing fibronectin in human atherosclerotic plaques are associated with a stable plaque phenotype," Atherosclerosis, vol. 195, no. 1, pp. e83-e91, 2007.

[225] M. Széll, Z. Bata-Csörgo, A. Koreck et al., "Proliferating keratinocytes are putative sources of the psoriasis susceptibilityrelated EDA+ (extra domain A of fibronectin) oncofetal fibronectin," Journal of Investigative Dermatology, vol. 123, no. 3, pp. 537-546, 2004.

[226] K. M. Ting, D. Rothaupt, T. S. McCormick et al., "Overexpression of the oncofetal Fn variant containing the EDA splice-in segment in the dermal-epidermal junction of psoriatic uninvolved skin," Journal of Investigative Dermatology, vol. 114, no. 4, pp. 706-711, 2000.

[227] S. Satoi, H. Kitade, Y. Hiramatsu et al., "Increased extra domain-A containing fibronectin and hepatic dysfunction during septic response: an in vivo and in vitro study," Shock, vol. 13, no. 6, pp. 492-496, 2000.

[228] J.-N. Rybak, C. Roesli, M. Kaspar, A. Villa, and D. Neri, “The extra-domain A of fibronectin is a vascular marker of solid tumors and metastases," Cancer Research, vol. 67, no. 22, pp. 10948-10957, 2007. 
[229] A. Villa, E. Trachsel, M. Kaspar et al., "A high-affinity human monoclonal antibody specific to the alternatively spliced EDA domain of fibronectin efficiently targets tumor neovasculature in vivo," International Journal of Cancer, vol. 122, no. 11, pp. 2405-2413, 2008.

[230] R. Kruse, M. Merten, K. Yoshida, A. Schmidt, W. Völker, and E. Buddecke, "Cholesterol-dependent changes of glycosaminoglycan pattern in human aorta," Basic Research in Cardiology, vol. 91, no. 5, pp. 344-352, 1996.

[231] M. Waterman, O. Ben-Izhak, R. Eliakim, G. Groisman, I. Vlodavsky, and N. Ilan, "Heparanase upregulation by colonic epithelium in inflammatory bowel disease," Modern Pathology, vol. 20, no. 1, pp. 8-14, 2007.

[232] S. Aotsuka, M. Okawa-Takatsuji, M. Kinoshita, and R. Yokohari, "Analysis of negatively charged dye-binding antibodies reactive with double-stranded DNA and heparan sulfate in serum from patients with rheumatic diseases," Clinical and Experimental Immunology, vol. 73, no. 3, pp. 436-442, 1988.

[233] E. Cohen, I. Doweck, I. Naroditsky et al., "Heparanase is overexpressed in lung cancer and correlates inversely with patient survival," Cancer, vol. 113, no. 5, pp. 1004-1011, 2008.

[234] E. A. McKenzie, "Heparanase: a target for drug discovery in cancer and inflammation," British Journal of Pharmacology, vol. 151, no. 1, pp. 1-14, 2007.

[235] A. Porto, R. Palumbo, M. Pieroni et al., "Smooth muscle cells in human atherosclerotic plaques secrete and proliferate in response to high mobility group box 1 protein," FASEB Journal, vol. 20, no. 14, pp. 2565-2566, 2006.

[236] S. Devaraj, M. R. Dasu, S. H. Park, and I. Jialal, "Increased levels of ligands of Toll-like receptors 2 and 4 in type 1 diabetes," Diabetologia, vol. 52, no. 8, pp. 1665-1668, 2009.

[237] K. Popovic, M. Ek, A. Espinosa et al., "Increased expression of the novel proinflammatory cytokine high mobility group box chromosomal protein 1 in skin lesions of patients with lupus erythematosus," Arthritis and Rheumatism, vol. 52, no. 11, pp. 3639-3645, 2005.

[238] M. Ek, K. Popovic, H. E. Harris, C. S. Nauclér, and M. Wahren-Herlenius, "Increased extracellular levels of the novel proinflammatory cytokine high mobility group box chromosomal protein 1 in minor salivary glands of patients with Sjögren's syndrome," Arthritis and Rheumatism, vol. 54, no. 7, pp. 2289-2294, 2006.

[239] A. Yoshizaki, K. Komura, Y. Iwata et al., "Clinical significance of serum HMGB-1 and sRAGE levels in systemic sclerosis: association with disease severity," Journal of Clinical Immunology, vol. 29, no. 2, pp. 180-189, 2009.

[240] R. Riganò, E. Profumo, B. Buttari et al., "Heat shock proteins and autoimmunity in patients with carotid atherosclerosis," Annals of the New York Academy of Sciences, vol. 1107, pp. 110, 2007.

[241] W. Van Eden, G. Wick, S. Albani, and I. Cohen, "Stress, heat shock proteins, and autoimmunity: how immune responses to heat shock proteins are to be used for the control of chronic inflammatory diseases," Annals of the New York Academy of Sciences, vol. 1113, pp. 217-237, 2007.

[242] W. E. Peetermans, G. R. D’Haens, J. L. Ceuppens, P. Rutgeerts, and K. Geboes, "Mucosal expression by B7-positive cells of the 60-kilodalton heat-shock protein in inflammatory bowel disease," Gastroenterology, vol. 108, no. 1, pp. 75-82, 1995.

[243] S. Hu, et al., "The expression of molecular chaperone HSP90 and IL-6 in patients with systemic lupus erythematosus,"
Journal of Huazhong University of Science and Technology. Medical Sciences, vol. 26, no. 6, pp. 664-666, 2006.

[244] C. Cid, M. García-Villanueva, M. Salinas, and A. Alcázar, "Detection of anti-heat shock protein $90 \beta$ (Hsp90 $\beta$ ) antibodies in cerebrospinal fluid," Journal of Immunological Methods, vol. 318, no. 1-2, pp. 153-157, 2007.

[245] C. Cid, I. Regidor, P. D. Poveda, and A. Alcazar, "Expression of heat shock protein 90 at the cell surface in human neuroblastoma cells," Cell Stress \& Chaperones, vol. 14, no. 3, pp. 321-327, 2009.

[246] M. Matysiak, B. Makosa, A. Walczak, and K. Selmaj, "Patients with multiple sclerosis resisted to glucocorticoid therapy: abnormal expression of heat-shock protein 90 in glucocorticoid receptor complex," Multiple Sclerosis, vol. 14, no. 7, pp. 919-926, 2008.

[247] N. R. Seung, E. J. Park, C. W. Kim, et al., "Comparison of expression of heat-shock protein 60, Toll-like receptors 2 and 4 , and T-cell receptor $\gamma \delta$ in plaque and guttate psoriasis," Journal of Cutaneous Pathology, vol. 34, no. 12, pp. 903-911, 2007.

[248] C. Kee, K. Y. Cheong, K. Pham, G. W. Waterer, and S. E. L. Temple, "Genetic variation in heat shock protein 70 is associated with septic shock: narrowing the association to a specific haplotype," International Journal of Immunogenetics, vol. 35, no. 6, pp. 465-473, 2008.

[249] S. Messaoudi, J. F. Peyrat, J. D. Brion, and M. Alami, "Recent advances in Hsp90 inhibitors as antitumor agents," AntiCancer Agents in Medicinal Chemistry, vol. 8, no. 7, pp. 761782, 2008.

[250] W. Luo, A. Rodina, and G. Chiosis, "Heat shock protein 90: translation from cancer to Alzheimer's disease treatment?" BMC Neuroscience, vol. 9, supplement 3, article S7, 2008.

[251] J. Witter, P. J. Roughley, and C. Webber, "The immunologic detection and characterization of cartilage proteoglycan degradation products in synovial fluids of patients with arthritis," Arthritis and Rheumatism, vol. 30, no. 5, pp. 519529, 1987.

[252] A. Yoshizaki, Y. Iwata, K. Komura et al., "Clinical significance of serum hyaluronan levels in systemic sclerosis: association with disease severity," Journal of Rheumatology, vol. 35, no. 9, pp. 1825-1829, 2008.

[253] K. N. Sugahara, T. Hirata, H. Hayasaka, R. Stern, T. Murai, and M. Miyasaka, "Tumor cells enhance their own CD44 cleavage and motility by generating hyaluronan fragments," Journal of Biological Chemistry, vol. 281, no. 9, pp. 58615868, 2006.

[254] P. A. Henriksen and J.-M. Sallenave, "Human neutrophil elastase: mediator and therapeutic target in atherosclerosis," International Journal of Biochemistry and Cell Biology, vol. 40, no. 6-7, pp. 1095-1100, 2008.

[255] A. Piwowar, M. Knapik-Kordecka, and M. Warwas, "Concentration of leukocyte elastase in plasma and polymorphonuclear neutrophil extracts in type 2 diabetes," Clinical Chemistry and Laboratory Medicine, vol. 38, no. 12, pp. 12571261, 2000

[256] W. Fischbach, W. Becker, and J. Mossner, "Leucocyte elastase in chronic inflammatory bowel diseases: a marker of inflammatory activity?" Digestion, vol. 37, no. 2, pp. 88-95, 1987.

[257] P. Bugren, N. Rasmussen, B. Isaksson, and J. Wieslander, "Anti-neutrophil cytoplasm antibodies, anti-GBM antibodies and anti-dsDNA antibodies in glomerulonephritis," European Journal of Clinical Investigation, vol. 22, no. 12, pp. 783792, 1992. 
[258] C. M. Figueredo, A. Areas, F. R. Sztajnbok et al., "Higher elastase activity associated with lower IL-18 in GCF from juvenile systemic lupus patients," Oral Health \& Preventive Dentistry, vol. 6, no. 1, pp. 75-81, 2008.

[259] S. N. Wong, V. Shah, and M. J. Dillon, "Anti-neutrophil cytoplasmic antibodies in childhood systemic lupus erythematosus," European Journal of Pediatrics, vol. 154, no. 1, pp. 43-45, 1995.

[260] H. Tsujimoto, S. Ono, T. Majima et al., "Neutrophil elastase, MIP-2, and TLR-4 expression during human and experimental sepsis," Shock, vol. 23, no. 1, pp. 39-44, 2005.

[261] J. A. Foekens, C. Ries, M. P. Look, C. Gippner-Steppert, J. G. M. Klijn, and M. Jochum, "The prognostic value of polymorphonuclear leukocyte elastase in patients with primary breast cancer," Cancer Research, vol. 63, no. 2, pp. 337-341, 2003.

[262] S. Shimada, K. Yamaguchi, M. Takahashi, and M. Ogawa, "Pancreatic elastase IIIA and its variants are expressed in pancreatic carcinoma cells," International Journal of Molecular Medicine, vol. 10, no. 5, pp. 599-603, 2002.

[263] K. Taniguchi, P. Yang, J. Jett et al., "Polymorphisms in the promoter region of the neutrophil elastase gene are associated with lung cancer development," Clinical Cancer Research, vol. 8, no. 4, pp. 1115-1120, 2002.

[264] M. M. McCormick, F. Rahimi, Y. V. Bobryshev et al., "S100A8 and S100A9 in human arterial wall: implications for atherogenesis," Journal of Biological Chemistry, vol. 280, no. 50, pp. 41521-41529, 2005.

[265] N. Lugering, R. Stoll, T. Kucharzik et al., "Immunohistochemical distribution and serum levels of the $\mathrm{Ca}^{2+}$ binding proteins MRP8, MRP14 and their heterodimeric form MRP8/14 in Crohn's disease," Digestion, vol. 56, no. 5, pp. 406-414, 1995.

[266] N. Lugering, R. Stoll, K. W. Schmid et al., "The myeloic related protein MRP8/14 (27E10 antigen)—usefulness as a potential marker for disease activity in ulcerative colitis and putative biological function," European Journal of Clinical Investigation, vol. 25, no. 9, pp. 659-664, 1995.

[267] H.-J. Haga, J. G. Brun, H. B. Berntzen, R. Cervera, M. Khamashta, and G. R. V. Hughes, "Calprotection in patients with systemic lupus erythematosus: relation to clinical and laboratory parameters of disease activity," Lupus, vol. 2, no. 1, pp. 47-50, 1993.

[268] R. Zenz, R. Eferl, L. Kenner et al., "Psoriasis-like skin disease and arthritis caused by inducible epidermal deletion of Jun proteins," Nature, vol. 437, no. 7057, pp. 369-375, 2005.

[269] D. Foell and J. Roth, "Proinflammatory S100 proteins in arthritis and autoimmune disease," Arthritis and Rheumatism, vol. 50, no. 12, pp. 3762-3771, 2004.

[270] K. Odink, N. Cerletti, J. Bruggen et al., "Two calcium-binding proteins in infiltrate macrophages of rheumatoid arthritis," Nature, vol. 330, no. 6143, pp. 80-82, 1987.

[271] P. Youssef, J. Roth, M. Frosch et al., "Expression of myeloid related proteins (MRP) 8 and 14 and the MRP8/14 heterodimer in rheumatoid arthritis synovial membrane," Journal of Rheumatology, vol. 26, no. 12, pp. 2523-2528, 1999.

[272] K. Wallner, C. Li, P. K. Shah et al., "Tenascin-C is expressed in macrophage-rich human coronary atherosclerotic plaque," Circulation, vol. 99, no. 10, pp. 1284-1289, 1999.

[273] K. Amin, D. Lúdvíksdóttir, C. Janson et al., "Inflammation and structural changes in the airways of patients with atopic and nonatopic asthma. BHR Group," American Journal of Respiratory and Critical Care Medicine, vol. 162, no. 6, pp. 2295-2301, 2000.
[274] E.-M. Karjalainen, A. Lindqvist, L. A. Laitinen et al., "Airway inflammation and basement membrane tenascin in newly diagnosed atopic and nonatopic asthma," Respiratory Medicine, vol. 97, no. 9, pp. 1045-1051, 2003.

[275] A. V. Ljubimov, R. E. Burgeson, R. J. Butkowski et al., "Basement membrane abnormalities in human eyes with diabetic retinopathy," Journal of Histochemistry and Cytochemistry, vol. 44, no. 12, pp. 1469-1479, 1996.

[276] M. A. M. Loots, E. N. Lamme, J. Zeegelaar, J. R. Mekkes, J. D. Bos, and E. Middelkoop, "Differences in cellular infiltrate and extracellular matrix of chronic diabetic and venous ulcers versus acute wounds," Journal of Investigative Dermatology, vol. 111, no. 5, pp. 850-857, 1998.

[277] S. Riedl, A. Tandara, M. Reinshagen et al., "Serum tenascin$\mathrm{C}$ is an indicator of inflammatory bowel disease activity," International Journal of Colorectal Disease, vol. 16, no. 5, pp. 285-291, 2001.

[278] R. Kaarteenaho-Wiik, E. Lakari, Y. Soini, R. Pollanen, V. L. Kinnula, and P. Paakko, "Tenascin expression and distribution in pleural inflammatory and fibrotic diseases," Journal of Histochemistry and Cytochemistry, vol. 48, no. 9, pp. 1257-1268, 2000.

[279] T. Paallysaho, K. Tervo, T. Kivela, I. Virtanen, A. Tarkkanen, and T. Tervo, "Cellular fibronectin and tenascin in an orbital nylon prosthesis removed because of infection caused by Staphylococcus aureus," Graefe's Archive for Clinical and Experimental Ophthalmology, vol. 231, no. 2, pp. 61-65, 1993.

[280] N. J. Gutowski, J. Newcombe, and M. L. Cuzner, "Tenascin-R and $\mathrm{C}$ in multiple sclerosis lesions: relevance to extracellular matrix remodelling," Neuropathology and Applied Neurobiology, vol. 25, no. 3, pp. 207-214, 1999.

[281] X. Chevalier, N. Groult, B. Larget-Piet, L. Zardi, and W. Hornebeck, "Tenascin distribution in articular cartilage from normal subjects and from patients with osteoarthritis and rheumatoid arthritis," Arthritis and Rheumatism, vol. 37, no. 7, pp. 1013-1022, 1994.

[282] M. Hasegawa, Y. Nakoshi, M. Muraki et al., "Expression of large tenascin-C splice variants in synovial fluid of patients with rheumatoid arthritis," Journal of Orthopaedic Research, vol. 25, no. 5, pp. 563-568, 2007.

[283] G. Orend and R. Chiquet-Ehrismann, "Tenascin-C induced signaling in cancer," Cancer Letters, vol. 244, no. 2, pp. 143163, 2006.

[284] R. A. Sobel and A. S. Ahmed, "White matter extracellular matrix chondroitin sulfate/dermatan sulfate proteoglycans in multiple sclerosis," Journal of Neuropathology and Experimental Neurology, vol. 60, no. 12, pp. 1198-1207, 2001.

[285] C. Ricciardelli, A. J. Sakko, M. P. Ween, D. L. Russell, and D. J. Horsfall, "The biological role and regulation of versican levels in cancer," Cancer and Metastasis Reviews, vol. 28, no. 1-2, pp. 233-245, 2009. 


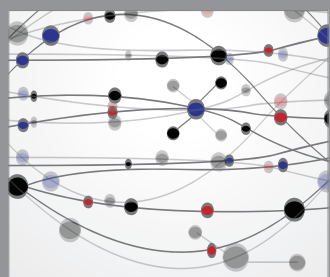

The Scientific World Journal
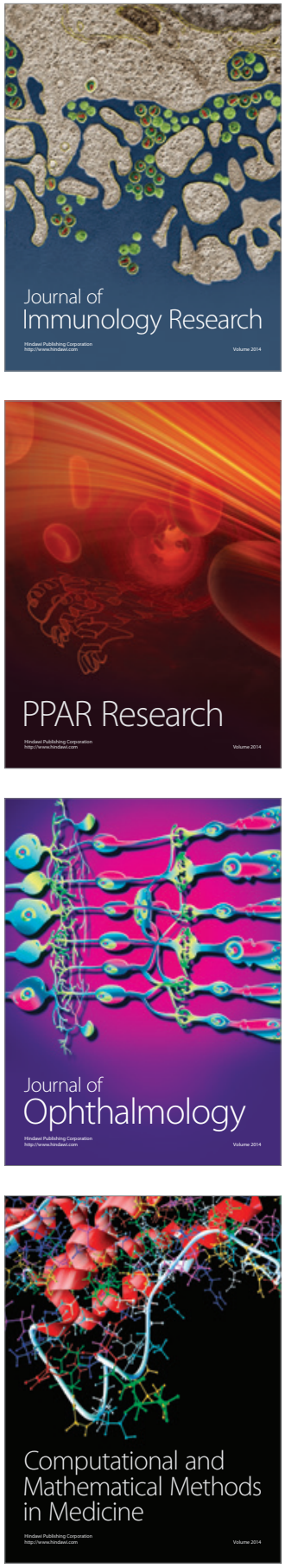

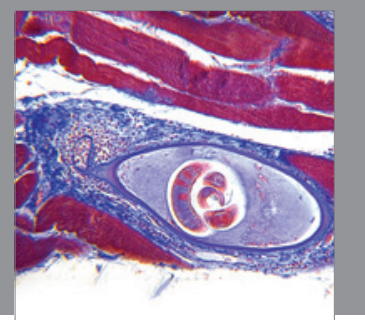

Gastroenterology

Research and Practice
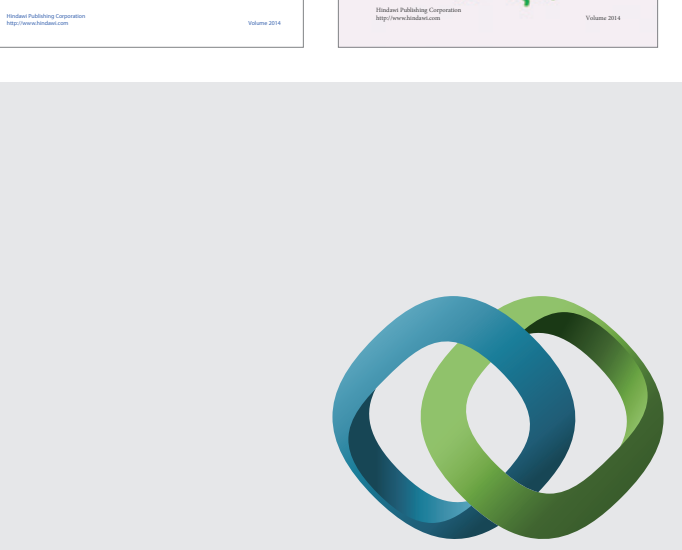

\section{Hindawi}

Submit your manuscripts at

http://www.hindawi.com
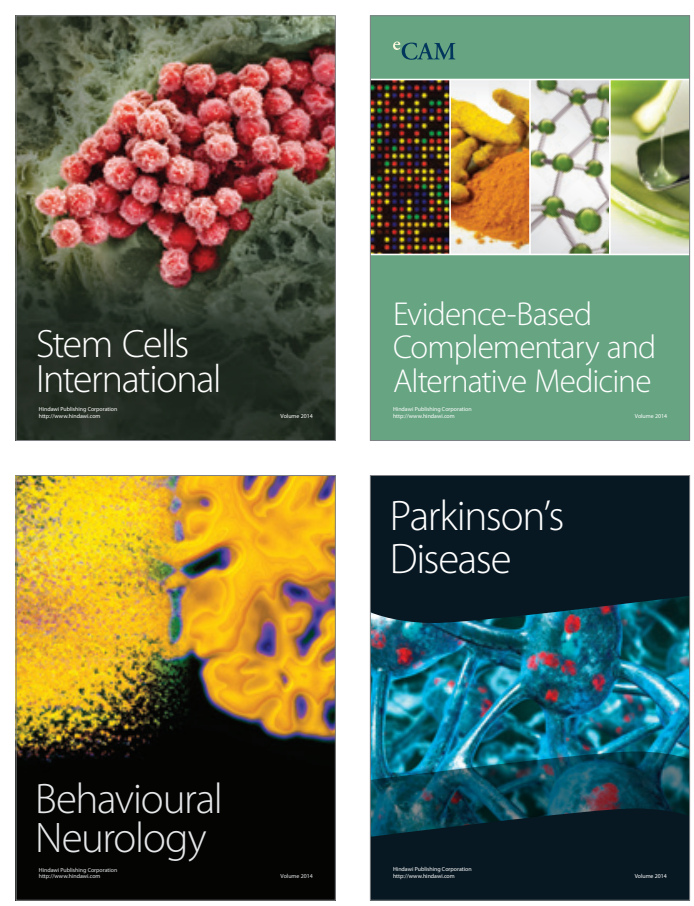

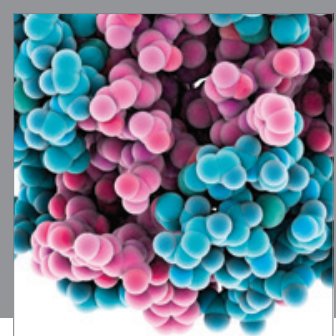

Journal of
Diabetes Research

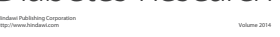

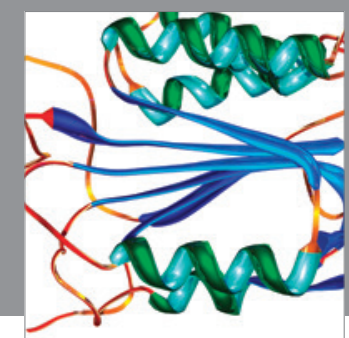

Disease Markers
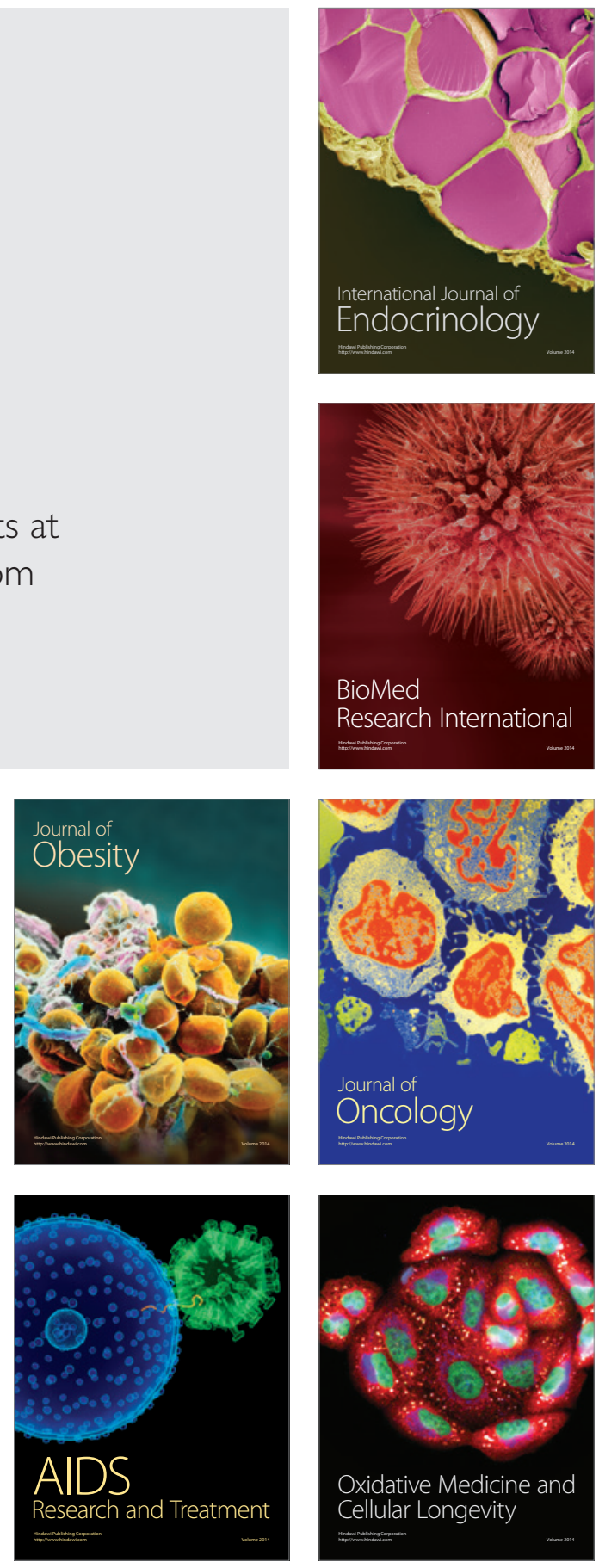